\title{
The Role of Hard Law in the WTO and China in Regulating Economic Transactions
}

By

\author{
Jiali Guo \\ A thesis submitted to \\ The Faculty of Graduate Studies and Research \\ in partial fulfilment of \\ the degree requirements of \\ Master of Arts-Legal Studies
}

\author{
Department of Law \\ Carleton University \\ Ottawa, Ontario, Canada \\ (January 2009) \\ Copyright $(\mathbb{C}$ \\ (2009) - Jiali Guo
}


Library and

Archives Canada

Published Heritage

Branch

395 Wellington Street

Ottawa ON K1A 0N4

Canada
Bibliothèque et

Archives Canada

Direction du

Patrimoine de l'édition

395 , rue Wellington

Ottawa ON K1A 0N4

Canada

Your file Votre référence

ISBN: 978-0-494-51977-6

Ourfile Notre référence

ISBN: 978-0-494-51977-6

NOTICE:

The author has granted a nonexclusive license allowing Library and Archives Canada to reproduce, publish, archive, preserve, conserve, communicate to the public by telecommunication or on the Internet, loan, distribute and sell theses worldwide, for commercial or noncommercial purposes, in microform, paper, electronic and/or any other formats.

The author retains copyright ownership and moral rights in this thesis. Neither the thesis nor substantial extracts from it may be printed or otherwise reproduced without the author's permission.
AVIS:

L'auteur a accordé une licence non exclusive permettant à la Bibliothèque et Archives Canada de reproduire, publier, archiver, sauvegarder, conserver, transmettre au public par télécommunication ou par l'Internet, prêter, distribuer et vendre des thèses partout dans le monde, à des fins commerciales ou autres, sur support microforme, papier, électronique et/ou autres formats.

L'auteur conserve la propriété du droit d'auteur et des droits moraux qui protège cette thèse. $\mathrm{Ni}$ la thèse ni des extraits substantiels de celle-ci ne doivent être imprimés ou autrement reproduits sans son autorisation.
In compliance with the Canadian

Privacy A'ct some supporting forms may have been removed from this thesis.

While these forms may be included in the document page count, their removal does not represent any loss of content from the thesis.
Conformément à la loi canadienne sur la protection de la vie privée, quelques formulaires secondaires ont été enlevés de cette thèse.

Bien que ces formulaires aient inclus dans la pagination, il n'y aura aucun contenu manquant.

\section{Canadä}




\begin{abstract}
:
International law plays an important role in regulating international affairs. It has been constructed in two ways: hard law and soft law, each of these forms has its uniqueness and cannot be substituted for the other. In this thesis, I first discuss the general principle of international law and the framework of hard law and soft law. Second, I deal with how the rule orientated WTO has evolved from its diplomatic orientated predecessor GATT; demonstrate why contracting parties of the GATT prefer hard legalization and eventually established the WTO. Third, I seek to demonstrate why the WTO rules are amiable to China's accession to the WTO, and how China's approach towards dispute settlement has changed after its accession. In the final section, I indicate the way China would behave in the dispute settlement process in the WTO. In this way, I seek to explore the role soft law and hard law play in international economic regulations, why the WTO was established as an organization that favoured hard legalization, how China adjusted into the WTO and why China's approach towards dispute settlement has been described as "aggressive legalism".
\end{abstract}




\section{Acknowledgement}

I wish to thank all of those who helped me to complete this thesis, both directly and indirectly, to achieve another milestone in my education. I wish to thank Professor Anthony VanDuzer for his acceptance to act as the External Examiner for my defence. I wish to thank Andrew Squries, who helped me with every little question that I had towards complementation of this degree. I am very grateful to Professor Neil Sargent for his encouragement, guidance and comments throughout my undergraduate and graduate studies at Carleton University. I have been very fortunate with my thesis Supervisor Professor Paul Davidson, his dedication to law and to the teaching profession broadened my vision of the field of international law. The most important skill that I gained from him is to organize and to set priorities and I believe this skill will be my life-time asset. Being my supervisor is not an easy task. As a foreign student, my language skills and my way of thinking actually doubled Professor Davidson's work load compared with other thesis supervisors. But he never lost his confidence in me; his patient guidance and advice encouraged me and cheered me up. I have greatly appreciated this guidance and advice, and I take this opportunity to express my deepest appreciation to Professor Davidson. Finally, I owe a great deal to my parents, who patiently support me with everything I need throughout all my studies from elementary school until the present. It is the support and encouragement of all these individuals and others, too many to be mentioned, that gives me the energy and strength to accomplish my goal of this degree. 


\section{Table of Content}

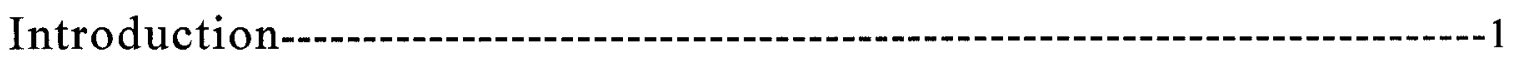

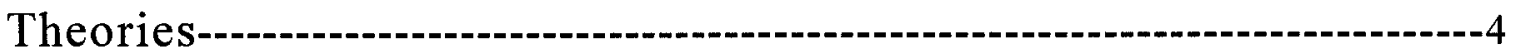

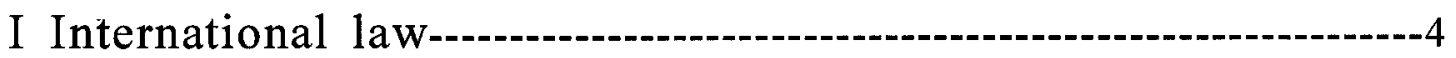

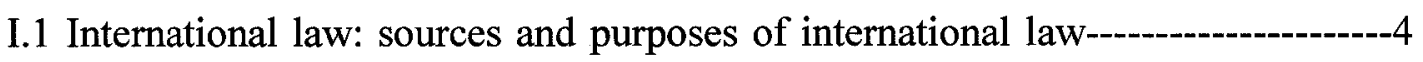

I.2 Is International Law really Law? --------o-

I.2(a) Austinian approach-----international law is not law----------------6

I.2(b) D'Amato's entitlement-based theory-------7

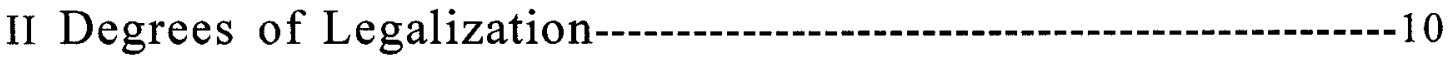

II.1 Three elements of the concept of legalization----

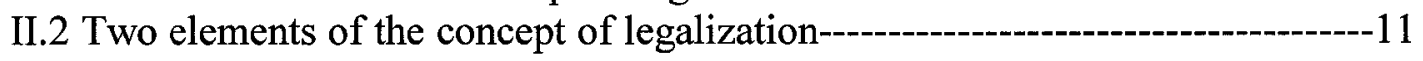

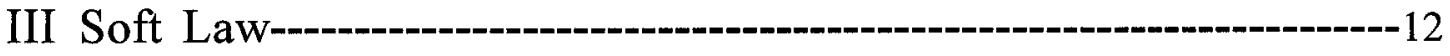

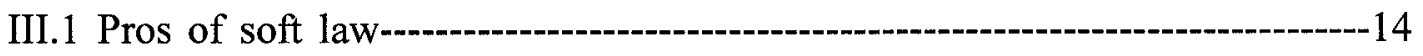

III.2 Cons of soft Law---

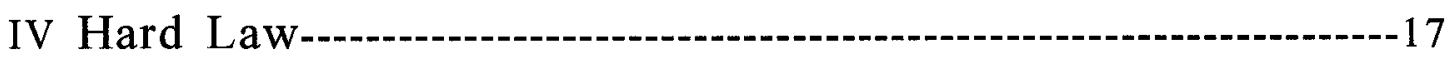

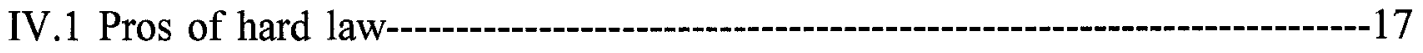

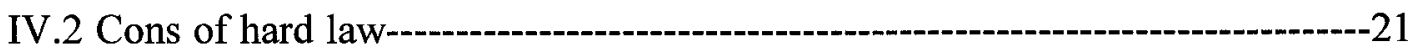

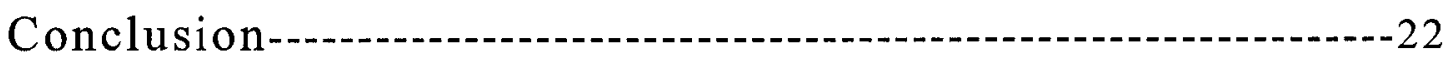

\section{Application of the Theories in GATT, the WTO and China}

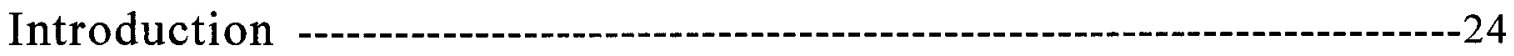

I The GATT --.--

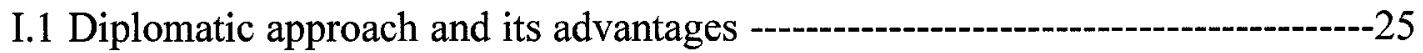

I.2 The Dispute Settlement under the GATT 1947 ----------------------------26

I.3 rule-orientated development of the GATT ---

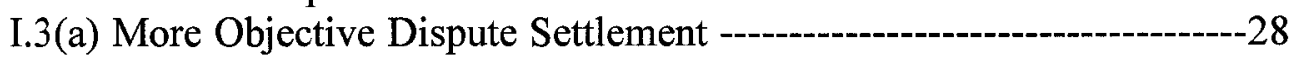

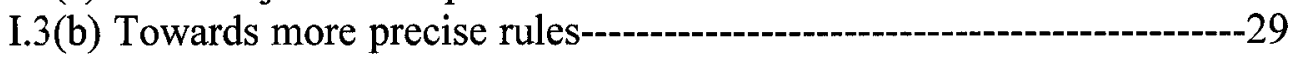

II The WTO--

II.1 DSM-the central success of the WTO as hard legal framework-------o-------31

II.2 WTO dispute settlement procedure reflects entitlement-based theory------------34

II.3 Why Members Prefer the WTO as a Hard Legal Regime-------------o----36

II.3 (a) Reasons for hard legalization-------------36

II.4 Flexible approach in hard legalization----WTO-----------o-----------38

II.5 Rationales behind China's Accession to the WTO-------------------------40

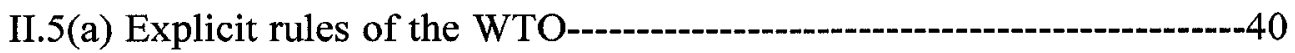

II.5(b) Binding obligation to show commitment---------------------41

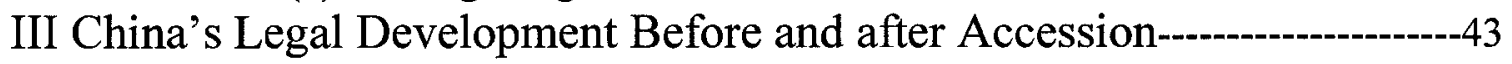

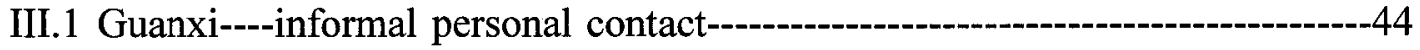

III.2 Dispute avoidance---

III.3 Legal Mobilization in China-Towards a Legalistic Approach -----_-_-_---.-48

III.3(a) Development of Commercial Law/Judiciary in China----------------49 
1. Massive law production: 1979-2001-

2. Law production: 2001-present--_-_-_-_-_-

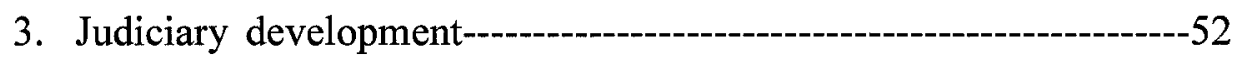

III.3(b) Legalistic Approach Both at Individual Level and International Level----53

1. Individual level------------------------------------------------------------53

2. International level. Comparison of Chinese practice at the international level before and after accession to the WTO----------54

IV China's Approach towards the WTO Dispute Settlement Mechanism ---57

IV.1 Reluctant User to Aggressive User---_-_-

IV.2 Cases under the WTO--

1. The US-China Steel Case-------------------------------------------------62

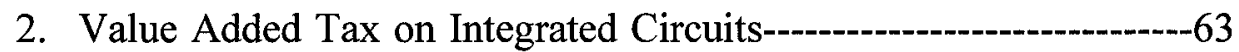

3. The China Auto Part Case----

IV.3 Will China's Aggressive Legalism under the WTO Lead to A Flood of

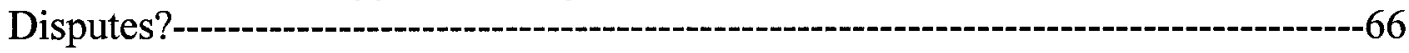

Conclusion-

Appendix 1 -

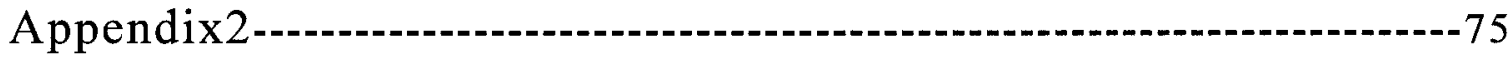

Appendix3 -

Biography

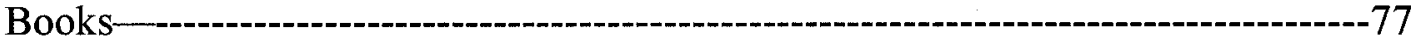

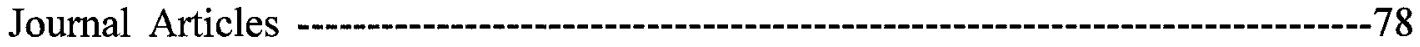

Electronic Sources from Official Institution Website-----------------------------------80

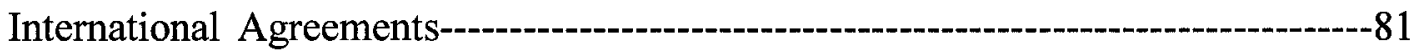

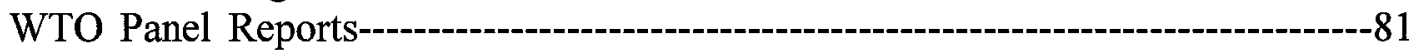

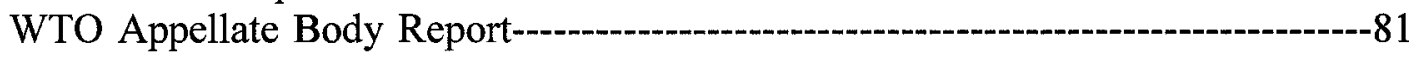

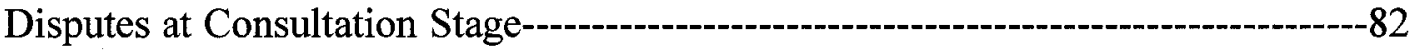

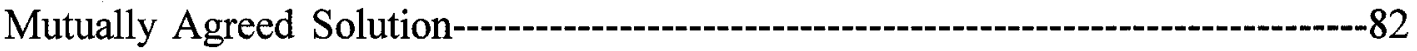

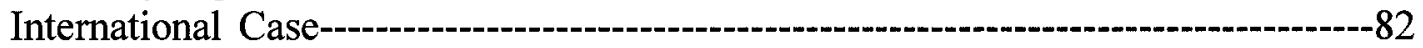




\section{List of Abbreviation}

$\begin{array}{ll}\text { APEC } & \text { Asia Pacific Economic Cooperation } \\ \text { DSB } & \text { Dispute Settlement Body } \\ \text { DSU } & \text { Dispute Settlement Understanding } \\ \text { EC } & \text { European Community } \\ \text { EU } & \text { European Union } \\ \text { GATT } & \text { General Agreement on Tariffs and Trade } \\ \text { ICSID } & \text { International Center for the Settlement of Investment Disputes } \\ \text { ITO } & \text { International Trade Organization } \\ \text { NAFTA } & \text { North American Free Trade Agreement } \\ \text { SCM } & \text { Subsidies and Countervailing Measures } \\ \text { SPS } & \text { Sanitary and Phytosanitary Measures } \\ \text { TRIMS } & \text { Trade Related Investment Measures } \\ \text { TRIPS } & \text { Trade Related Intellectual Property Rights } \\ \text { UN } & \text { United Nations } \\ \text { WTO } & \text { World Trade Organization }\end{array}$




\section{Introduction:}

International law has played an important role in regulating economic transactions. There are regional international agreements between states such as the NAFTA, the European Union, and multi-lateral frameworks such as the WTO. No matter whether the framework is regional or worldwide, they are all aim to remove trade barriers to achieve economic development among members. Probably all frameworks could be categorized as soft or hard: soft legalization is characterized as general rules with nonbinding obligations whereas hard legalization is characterized as explicit and precise rules with binding obligations.

The choice between soft law and hard law reflects the parties' wish to model their relationship in a way that excludes the application of treaty or customary law on the consequences of a breach of obligations. It would appear more appropriate to consider the extent to which the parties chose to bind themselves, and what legal consequences they wanted to attach to their agreement. The terms of the GATT 1947 (the predecessor of the WTO) were imprecise and the levels of obligation and delegation of dispute settlement were relatively low. Over years of practice, members found they needed a rule-orientated framework to ensure certainty and practicability with an effective dispute settlement mechanism. Based on this preference, the WTO, probably the most successful international regime based on hard legalization, which has 153 members (as of 23 July, 2008), was established in 1994. At the heart of the WTO are a series of agreements which are legal rules that set up rights and obligations of members and bind governments to keep their actions within the prescribed limits. In addition, the most successful pillar of the WTO as a form of hard legalization is its Dispute settlement 
mechanism which sets up a neutral third party to give a binding decision. Thus, rights and obligations of members can be effectively enforced.

It took China 15 years to accede to the WTO and become a member in late 2001. The driving force for China to be a member is the perceived economic opportunities with the WTO members and the security that the WTO offers. Security here has two meanings: as a member of the WTO, China can trade with others in a secure and predictable rule-based multilateral trading system. On the other hand, by binding itself to the WTO obligations, other members feel secure to trade with China.

By being a member of the WTO, China is able to participate in the WTO dispute settlement mechanism. The Chinese traditional Confucianism which preaches harmony and perceives confrontation as aggressive behaviour, might suggest that China would opt to solve conflicts through negotiation or mediation rather than adjudication. However, evidence shows that adjudication has gained popularity as the Chinese legal system is becoming more and more sophisticated. Practices in the WTO also reflect this trend and China is considered as taking aggressive legalism, which means utilizing the WTO rules to solve conflicts with its trading partners. Chinese government officials have also made comments at the international stage that suggest China would take legal measures to protect its trading rights. All of these show that as China becomes more familiar with the system, it feels more comfortable with the WTO dispute settlement mechanism and takes an increasingly legalistic approach to solve its disputes with trading partners.

This paper is comprised of three chapters to explore the role hard law plays in regulating international economic transactions from a theoretical and practical 
standpoint. Chapter One examines sources of international law, and discusses opposite approaches from John Austin and Anthony D'Amato to determine whether international law is law, the doctrines of hard law and soft law and their respective pros and cons, and the role they play in international law. Chapter Two examines the development of the GATT from a diplomatic (soft law) to more of rule-based (hard law) regime to satisfy members' need for certainty and predictability. The chapter further discusses the establishment of the WTO as a hard legal framework, which is different from its predecessor the GATT, to govern international economic transactions. The success of the WTO as an international legal framework evidences that international law is law, and it does have the capacity to achieve its goal of maintaining its subjects in order and facilitating development. Besides discussion of the evolution from the GATT to the WTO, Chapter Two also examines why China is taking a legalistic approach to regulate economic matters, and the incentives behind China's accession to the WTO; and explores how this increasingly legalistic approach at both domestic and international levels resembles the changing nature from the GATT to the WTO. This is further examined in the context of China's changing approach to dispute settlement within the WTO. The final chapter of the thesis sums up that any type of international law, either hard or soft, can be successful in regulating economic affairs. The choice between them merely reflects the way members model their relationship. Although the WTO has developed a "harder" legal framework, the WTO recognizes the merits of both types of law, and contains soft measures as well as hard law. Although China has taken an increasingly legalistic approach to regulating economic relations, China still prefers to resort to consultation for dispute settlement. 


\section{The Theories}

In this section, the main theme is to explore international law in general and the role of hard law/soft law. The focus of this section is to introduce hard law and soft law with their pros and cons respectively. In this section, first of all, sources and purposes of international law will be briefly introduced. Secondly, two theories from John Austin and Anthony D'Amato regarding whether international law is real law will be examined. Thirdly, concepts of legalization from Abbott and Davidson will be introduced. Fourthly, pros and cons of soft law legalization and hard law legalization will be discussed. Last but not least, transformations between hard law and soft law will be examined.

\section{International law}

\section{I.1 International law: sources and purposes of international law}

International law is a set of rules set to govern relationships within international society. These laws range from bilateral laws between two states to multilateral laws among a larger community of states. International laws, most of the time, have been defined as laws among states. However, the scope of international law has been broadened. In the last century, government officials and individuals have also been included into international law, especially international human rights law. In the international economic law field, subjects do not have to be a sovereign state. Hong Kong, for example, as a part of China, is a member of the WTO.

Law, including international law, has threefold social functions: "carrying the structures and systems of society through time; inserting the common interest of society into the behaviour of society members; establishing possible futures for society, 
in accordance with society's theories, values and purposes." Different scholars have different standpoints of the objectives of international law. One thing certain about international law is that the main purpose of international law is to maintain peace and justice, as well as cover other interests of state members. These interests include: political values, economic gains and other preferences of various international actors. These incentives for making international laws are always there, however, the priority of them is ever changing. After the Second World War, peace and balancing the power of communist countries became the new main interest of the West. It is in this period that NATO was set up. At the same time, rebuilding the Western economy was also the main interest, the Bretton Woods System was set up.

There are various sources of international law. Article 38 of the International Court of Justice (ICJ) sets out a number of sources of international law which include: treaties and international conventions, whether general or particular; established rules expressly recognized by the contesting parties; international custom, as evidence of general practice accepted as law; the general principles of law recognized by civilized nations; and subsidiary sources of judicial decisions and legal teachings. As we move on to discuss international hard law and soft law, we will notice that most treaties/conventions fall into the hard law category while most subsidiary sources fall into the soft law category.

\section{I.2 Is International Law really Law?}

Unlike for domestic laws, there is no executive body or legislative body to make international laws and govern them. At the domestic level, all citizens are subject to

\footnotetext{
${ }^{1}$ Caputo Tullio, Charles Reasons, Augistine Brannigan \& Mark Kennedy. Law and Society, a Critical Perspective (Toronto: Harcourt Brace Jovanovich, Canada 1989) at 31.
} 
their sovereign power and to their domestic law. Any actions that go against their laws lead to consequences. At the international level, each state has its sovereign power and is not subject to any other state members. Thus, how is international law enforced against another state especially a superpower such as the United States? If international law cannot be enforced, is it really law? Two approaches towards this question whether international law can be considered as law will be examined in the following. One is from John Austin, a legal positivist who considered international law as moral rules rather than real positive law; the other is from Anthony D'Amato who considers international law as law.

\section{I.2(a) Austinian approach-----international law is not law}

Legal positivism is the theory that the existence and content of law depends on social facts and not on its merits. Law is a matter of what has been posited and law is a social construction. ${ }^{2}$ Legal positivism stands in opposition to various contrary ideas in the tradition of natural law. It separates law, morality and ethics. Thus, legal validity has no essential connection with morality or justice. A law is a valid law if posited, in the proper manner, by a recognized authority, regardless of its moral implications.

John Austin is best known for his work developing the theory of legal positivism. Two points that are important to Austin's theory of positive law, are sovereign's command and sanction. According to Austin, law, more specifically, positive law is comprised of commands from a sovereign body that are backed by sanctions. The term "sovereign" could be a person or office or institution which embodies supreme

\footnotetext{
${ }^{2}$ Stanford Encyclopedia Of Philosophy. "Legal Positivism", available at http://plato.stanford.edu/entries/legal-positivism/, last accessed on 15 June, 2008.
} 
authority and who is habitually obeyed by its population. Rules are general commands which involve expressly what should be done; sanctions will be imposed if commands are not fulfilled or not complied with.

Austin argued that international law is positive morality rather than positive law, because he considered international law was set up by general opinions of sovereigns and was not clothed with legal sanctions. The body set up by this opinion is indeterminate and it does not embrace the power to command. Accordingly, the body lacks power to manipulate its agents to enforce its command. Due to these inherent shortcomings, international law cannot fulfill Austin's theory of positive law. (i.e. powerful sovereign and command backed by sanction). Within international law, or positive morality as Austin called it, one sovereign A could command sovereign B to forbear from a kind of conduct which is forbidden. However, this would not amount to a positive law, because a command must be made to a subject. In the international realm, every nation is sovereign and not subject to any other nation. Hence, a command from sovereign A to sovereign B does not make this international law as positive law.

\section{I.2(b) D'Amato's entitlement-based theory}

D'Amato argues that international law does exist. Not only does international law exist, it has functions similar to domestic law. The absence of legal institutions and a world police force to enforce rules does not mean that international law is not law; rather, it simply means that international law is enforced in a different way. ${ }^{3}$

\footnotetext{
${ }^{3}$ Anthony D'Amato. International Law: Process and Prospect (New York: Transnational Publishers Inc. 1995) at 24.
} 
In the debate over whether international law is real law or not, one point that has been discussed is that compared with domestic law, international law lacks enforcement. D'Amato argues that international law does have enforcement through social-disapproval and deprivation of entitlements of the state which is at fault.

Unlike Austin's approach that law is separate from morality, D'Amato argues that social-disapproval discourages people who would disobey the law, thus, morality may be potent enough to deter people who might break laws and enforce legal rules. In the same sense, social-disapproval works the same way to discourage states from breaking international law. Besides including morality into the forms of enforcement, D'Amato develops his entitlement-based theory to further discussion of international law enforcement. D'Amato argues that in any legal framework, subjects have their legal entitlements and their entitlements would be deprived if they offend any law. Under domestic law, a person put into prison loses his entitlement of liberty; a person loses his entitlement of property if his bank account is frozen by law, etc. According to D'Amato, "in all cases of law violation, the law responds by depriving you of one or more of your entitlements." At the international level, "a nation is nothing more or less than a bundle of entitlements." 5 Hence, every nation possesses the same entitlements and these entitlements are protected by threat of reciprocal entitlements violations. That is, under international law, if state A violates the entitlement of State B, State B's reciprocal violation of State A's entitlement would not be condemned. As the result, a state will be hesitant to violate law to offend another state because of the possibility of reciprocal violation.

\footnotetext{
${ }^{4}$ Ibid. at 14.

5 Ibid. at 19.
} 
Austin's approach towards positive law involves a sovereign and sanctions to enforce rules. For Austin, enforcement is always accompanied with physical coercion by sovereign's power. Since there is no supreme sovereign power that all state members are subject to and physical enforcements cannot be put onto state members, international law does not exist. This approach towards enforcement is narrow, it is more suitable to criminal law where a person has committed an illegal act, and he will be physically punished. According to Austin, only harsh sanctions rather than morality would lead subjects to compliance with law. D'Amato takes a different perspective; he concedes that physical coercion is not a necessary component of law. Rather, morality such as socialdisapproval works as one way of enforcement. He then furthers the true meaning of enforcement as to take away the entitlement of the party at fault. Thus, no matter which form the enforcement takes, its ultimate effect is to take always one's entitlement. International law, through deprivation of entitlement of a state, achieves its enforcement of rules.

I agree with D'Amato's approach that international law is law. The ultimate goal of law is to ensure the social order. At the domestic level, sanction by physical coercion is effective to make individuals comply with laws; whereas at the international level, sovereign states cannot be physically coerced, and deprivation of entitlement is effective for compliance. Thus, despite the measures a law takes, as long as it achieves its goal to maintain the social order, it is law. In this sense, as long as international laws achieve the ultimate goal, they are laws. As we will see in the next chapter, one factor that makes the WTO successful is its Dispute Settlement Measures 
which allows deprivation of entitlement through suspension of obligation. More on this will be discussed in the next chapter.

\section{Degrees of Legalization}

At the international level, some international laws have a strong effect on states while other laws have a very weak effect. This can be categorized as degree of legalization. There are various definitions of legalization and measurements of legalization. In this section, two definitions will be introduced. One is from "The concept of Legalization" " by Abbott, etal. which discusses three characteristics to determine legalization, while the other one proposed by Professor Paul Davidson from Carleton University contains two elements to determine legalization. Although the two approaches differ slightly, they both describe the degree of the elements of legalization, ranging from very weak to strong and conclude that there is seldom pure hard legalization or soft legalization. Some rules are hard orientated while others are soft orientated, but most laws have both aspects, particularly international law.

\section{II.1 Three elements of the concept of legalization}

According to Abbott etal., Legalization refers to a particular set of characteristics that institutions may or may not possess. These characteristics include: obligation, precision and delegation. According to Abbott etal., obligations refer to the rules which state members are legally bound by, their behaviours are subject to scrutiny of these rules, procedures and discourse of international law; precision refers to how the rules which define how state members behave are without ambiguity; delegation refers to a neutral authorized third party to interpret, implement and resolve problems based on the

\footnotetext{
${ }^{6}$ Kenneth W.Abbott, Robert O, Keohane, Andrew Moravcsik, Anne-Marie Slaughter, and Duncan Snidal "The Concept of Legalization" (2000) 54 no 3 International Organization 401 at 401.
} 
rules. ${ }^{7}$ Generally speaking, these three characteristics show the degree to which parties are bound by rules to which they have agreed to make a commitment.

According to Abbott etal., "each of these elements is a matter of degree and gradation, not a rigid dichotomy, and each can vary independently." 8 Thus, the characteristics of a norm will determine its degree of legalization. On one side of the spectrum, there is an ideal legalization where all these three elements are maximized while on the other end, there is an ideal type of legalization with absence of all of these three elements which means no legalization at all. However, either ideal type of legalization is hard to achieve. There is no legalization that perfectly maximizes all these three elements. Thus, we have various degrees of legalization in between. Some laws which highly emphasize all three elements especially obligation and delegation are considered as "hard law" while other laws which are weak on these three elements are considered as "soft law". Most laws are combinations of various degrees of these three elements; hard law may contain soft rules and soft law may embrace hard wording.

\section{II.2 Two elements concept of legalization}

Professor Davidson's two elements of legalization are rules and dispute settlement mechanism. Under the first element, rules range from binding obligation to non-binding obligation, precise rules to vague rules. Thus, the first element in Davidson's theory contains the first two characteristics of the three elements concept of legalization. Dispute settlement mechanisms can vary from formal (i.e. courtroom) to informal (i.e. mediation and conciliation) third party institutions and compliance may be ensured by formal or informal methods. Thus, Professor Davidson focuses on the dispute settlement

\footnotetext{
${ }^{7}$ Ibid.

${ }^{8}$ Ibid.
} 
mechanism which could vary from formalized third institution such as a court room to informal mechanisms such as negotiation to settle disputes.

Davidson has a similar approach to Abbott etal. towards legalization, that is, there is no clear distinction of soft and hard law, each of them is a combination of various degrees of different legalization elements. No matter which concept of legalization we take, both concepts have a lot of characteristics in common. Both of them are concerned with whether rules are binding or non-binding, with the precision of rules and whether the interpretation of the rules is formalized or not. They both set levels from weak to strong to measure these factors and conclude whether legalization is weak or strong.

At the international level, strong legalization is often referred to as hard law while weak legalization is often referred to as soft law. Some people argue that hard laws are laws that have all strong legalization factors while soft laws have weak legalization factors. However, most international laws are blended with some strong characteristics and some weak factors. The WTO, for example, as hard law, as most scholars agree, still has weak delegation because of the enforcement problem.

In the following, soft law and hard law will be discussed. Both pros and cons of each type of law will be examined.

\section{Soft Law}

According to the elements of legalization discussed above, the term soft law refers to the situation where the factors in legalization are weak. According to Chinkin, "Soft law instruments range from treaties, which noticeably include only soft obligations, to non-binding or voluntary resolutions and codes of conduct formulated and 
accepted by international and regional organizations, to statements prepared by individuals in a non-governmental capacity, but which purport to lay down international principles." $" 9$

Within a soft law regime, formality is avoided, and the maintenance of good relations is relied on for cooperation. According to Joseph Gold, "The essential ingredient of soft law is an expectation that the states accepting these instruments will take their content seriously and give them some measure of respect.",10

Soft law and Non-binding norms may be found in various places, including treaty provisions that call only for general cooperation among states or that bind states only to reach agreement on a matter in the future; non-treaty declarations or political pacts issued by states that set forth certain aspirations; resolutions of international organizations that are recommendatory in nature; and codes of behaviours that states or non-state actors are invited to adopt. One example of soft law can be found in APEC. APEC is an inter-governmental organization which facilitates economic development, cooperation and investment in the Asia-Pacific region. It operates on "nonbinding commitments, open dialogues and equal respect for the views of all participants. Decisions made within APEC are reached by consensus and commitments are undertaken on a voluntary basis." 11

\footnotetext{
${ }^{9}$ Christine M, Chinkin "The Challenge of Soft Law, Development and Change in International Law" (1989) 38 International \& Comparative Law Quarterly 850 at 851.

${ }^{10}$ Joseph Gold, "Strengthening the Soft International Law of Exchange Agreements" (1983) 77 no3 The American Journal of International Law 443 at 443.

${ }^{11}$ APEC Official website. About APEC assessed on 20 June, 2008 available at http://www.apec.org/apec/about_apec.html
} 


\section{III.1 Pros of soft law}

Starting from the 1970s, governments have turned to the soft law regime to seek economic and environmental cooperation. Davidson offers several advantages of international soft law in his paper "To Bind or not to Bind.",12

At the international level, soft law offers a flexible way for governments to cooperate and solve their problems. State members come into a soft law regime voluntarily and there are few obligations for members to be bound by, thus, the nonbinding nature of soft law provides state members opportunities to fashion their policies in the manner that best suits their changing situation. Furthermore, states are reluctant to accept binding rules and the non-binding nature enables state members to adopt soft law rules rather than hard law rules more easily. Hence, according to Kirton and Trebilcock, "timely action when governments are stalemated". 13

The rules are not as precise as highly legalized norms and thus leave more room for parties to negotiate. In addition, the general nature of rules of soft laws offers state members opportunities to negotiate and renegotiate as economic situations and their interests change.

Soft law is also useful to address cultural differences when both Western states and Eastern states are involved. Western states prefer rule--based legal regimes, while Eastern states prefer a relation-based legal framework. By applying a soft law

\footnotetext{
12 Paul Davidson. "To Bind or not to Bind. This is the question.: International Law and the Role of APEC in the Governance of a Free Trade Area of the Asia Pacific (FTAAP)" revised version of a paper presented at The Second All China Economics (ACE) International Conference, APEC Study Centre, City University of Hong Kong, Hong Kong, on December 12 - 14, 2007. Unpublished. A copy of this paper is on file with the author.

${ }^{13}$ John J Kirton \& Michael J. Trebilcock, Hard Choices, Soft Law: Voluntary Standards in Global Trade, Environment, and Social Governance (Vermont USA: Ashgate Publishing, 2004) at 5.
} 
framework, it gives both categories of states time to negotiate and to overcome their differences.

In addition, according to Professor Davidson, soft law also helps to avoid sovereignty issues. He mentions that when making laws with binding obligations, states might not be willing to negotiate binding obligations with states that are not fully recognized at the international level. However, states might negotiate non-binding obligations with those not fully recognized as states. To illustrate this, Professor Davidson gave the example that Mainland China, Hong Kong and Taiwan are all members of APEC.

Last but not least, Professor Davidson mentioned that "Adoption of nonbinding "soft law" may result in the adoption of more progressive norms than would be drafted if a "hard law" format had been chosen." 14

\section{III.2 Cons of Soft Law}

Although soft law offers various advantages, it has been subject to many criticisms.

1. The first challenge of soft law comes from its non-binding nature. It has been argued that since there are no obligations for state members to be bound by, and no obligations for implementing rules into domestic law, thus, even if a state member breaks some of the rules, it can just walk away from obligations without suffering major consequences.

2. Scholars argue that due to soft law's non-binding nature, it is not feasible to set up a formal dispute mechanism to ensure compliance. According to

\footnotetext{
${ }^{14}$ Ibid., note 12 , at 26
} 
Davidson, a managerial approach is more suitable for solving problems within a soft law regime; Davidson considers peer review as a good way of ensuring and encouraging compliance. According to Davidson, "Peer review refers to how co-workers evaluate among themselves to increase job efficiency and cooperation. At the international level, peer review can be described as the systematic examination and assessment of the performance of a state by other states." ${ }^{15}$ However, peer review can only encourage compliance, it does not have measures to ensure compliance.

3. Soft law does not have explicit rules but recommendations and guidelines. One of the functions of law is to offer certainty and prediction, which includes both explicit rules and consequences of breaking rules. Due to the lack of precise rules, not only the costs of inter-governmental transaction on negotiating agreements, implementation and dispute settlements are high; but also private actors' costs on risks under the uncertainty of the economic legal rules are also high compared with under the legal regime with certainty and predictability.

4. Another criticism of soft law is about the "slowness" of soft law. Since soft law has no detailed rules and counts on state members' cooperation, it is thus generally understood that "soft" law "creates and delineates goals to be achieved in the future rather than actual duties; programs rather than prescriptions; guidelines rather than strict obligations." ${ }^{.16}$ In addition, due to imprecise rules, frequent negotiations are needed. There is also a concern that if soft law spreads, there might be a chance that the world would be out of control since soft law provides no certainty, lacks responsibility and

\footnotetext{
${ }^{15}$ Davidson, supra, note 12, at 28.

${ }^{16}$ Anthony D'Amato, "Chapter 5 - Soft Law" in D'Amato, Anthony D'Amato and Kirsten Engel, International Environmental Law Anthology (Philadelphia US: Anderson Publishing Company 1997) at 56.
} 
accountability. As a result, there is a call for regulation. Scholars argue that the call for regulation is "not for the sake of regulation; it is perhaps not even a matter of regulation for the sake of bringing back a more structured form of politics. Instead, an important reason for this plea is to add in principles of accountability and responsibility. ${ }^{, 17}$ If there were a tendency that soft law would substitute hard law and be the only standard globally, this would be a concern. However, as we will continue to discuss, hard law and soft law are based on their own merits, they are not a substitute of each other. Rather, they will coexist. There will be no chance for one to substitute for the other.

\section{Hard Law}

Hard laws are laws where parties have binding obligations, precise wording of rules and a delegated authority to interpret rules, make decisions and enforce decisions. "Statutes or regulations in highly developed national legal systems are generally taken as prototypical of hard legalization." ${ }^{\prime 18}$ At the international level, the WTO is probably the most prominent example of international hard law. According to Abbott et al, "The WTO administers a remarkably detailed set of legally binding international agreements; it also operates a dispute settlement mechanism, including an appellate tribunal with significant—if not fully proven—authority to interpret and apply those agreements in the course of resolving particular disputes." ${ }^{.19}$

\section{IV.1 Pros of hard law}

1. The binding nature of hard law encourages members to make commitment. By entering into a binding legal regime, every member signals to the rest

\footnotetext{
17 Jan Klabbers, "Institutional Ambivalence by Design: Soft Organizations in International Law" (2001) 70 no3 Nordic Journal of International Law 403 at 420.

${ }_{18}$ Abbott et al, supra., note6, at 402.

${ }^{19}$ Ibid., at 405.
} 
that they will commit themselves to the law and all members assure the others that they will make the same commitment. Their behaviours are supervised by the law and if any event of non-compliance takes place, law will help victims to get compensated. Thus, hard laws encourage commitment to the greatest extent.

2. Precise legal rules ensure certainty and prediction. According to Abbott, "as a general proposition, increasing the level of detail in a written agreement should result in reducing ambiguity or uncertainty concerning its meaning. $" 20$ Detailed legal rules offer the state members clear predictions of what consequence they will bear if they break the law. Thus, hard law has a considerably stronger effect of preventing violation of the laws. Precise rules provide clearer signals to governments about the nature of their obligations. By clearly understanding the rules, frequent re-negotiations can be avoided, thus reducing intergovernmental bargaining subsequent to the conclusion of an agreement, and reducing the need to bargain over the mechanics of implementation. As the apparent scope for deviations from norms is reduced, governments should be less likely to differ over what measures are within and outside their prescriptions. According to Abbott, "The cost for negotiating precise rules will be lower than the bargaining transaction cost of elaborating the terms of an imprecise agreement, this is because the bargaining cost not only relates to cost imposed on governments to conduct negotiations but also includes delays in the implementation of commitments assumed to have beneficial economic welfare effects."21

Precise rules also help private actors to plan their economic transactions within the regime. Governments are the main actors to negotiate agreements while

\footnotetext{
${ }^{20}$ Frederick M. Abbott. "NAFTA and the Legalization of World Politics: A Case Study" (2000) 54 International Organization 519 at 524.

${ }^{21}$ Ibid., at 526.
} 
business activities are mainly conducted by private actors. For private businessmen, they prefer an economic environment where rules are explicit and known to everybody. Thus, they can make sure they are applying the same legal rules with their trading partners. Hence, precise rules reduce the need to insure against risks, reduce the cost of doing business, and increase the prospects that transactions will be undertaken. As a result, a greater certainty leads to more smooth private economic transactions, brings more business opportunities and enhances the prosperity of the states.

Precise rules also prevent strategic behaviour from both government and private actors. Since rules are explicit and known to the ultimate private users, parties know exactly what actions are permitted and what behaviours are prohibited. As a result, chances of the rules being taken advantage of are reduced to the lowest level.

Precise rules could even help members in a dispute to get resolutions much faster than soft law. Hard laws, even if hard laws with weak delegation function, set up rules and procedures of resolving disputes. Basic principles are recognized so that parties negotiate within a framework and this saves time. Furthermore, all bargains and negotiations that parties undertake must comply with legal rules. Hence, fixed but explicit rules could even solve disputes faster.

3. Consistency is another advantage that hard law offers. Compared with soft law, hard law has a formal dispute settlement mechanism which applies precise rules. Under the dispute mechanism, all legal rules are interpreted by an authorized institution. Thus, hard law achieve the level of consistency seldom seen among soft laws. This is very different from soft laws. Soft laws only set out general principles that can be interpreted by different experts among state members. Thus, interpretation of soft law 
general principles among state members may vary and this causes inconsistency of legal rules.

4. Under a hard law regime, the reputation cost would be higher. Reputations cost can be found in any legal system, whether hard or soft. However, in a hard regime, if parties go through settlement measures all the way to adjudication, all allegations, and defences are tested under the accepted standards, an increase of reputational cost would be found if there is indeed a violation. ${ }^{22}$

5. A rule-orientated legalization could help to reduce the power of members' to the lowest level. A final resolution of any dispute is made by an independent third party according to the rules of the system, rather than simply by negotiations between the parties, where the party with the stronger economic, political or even military power has more leverage than the other party. In the WTO, one of the WTO's first disputes, centred on a complaint brought by Costa Rica against the United States. The panel found in favour of Costa Rica, and the United States complied with the panel decision. $^{23}$

6. Hard law provides settlements to legal violations. Parties can proceed to adjudication to get their disputes settled. Based on the precise fixed rules, a neutral third party makes decisions by applying appropriate provisions of laws to the facts of a particular conflict and supervises the implementation of its decision. As a result, the losing party is obliged to make commitments to correct its wrongful acts and fulfill

\footnotetext{
${ }^{22}$ Kenneth W. Abbott \& Duncan Snidal. "Soft and Hard law in International Governance" (2000) 54 no3 International Organization 421 at 427

${ }^{23}$ Panel Report in United States-Restrictions on Imports of Cotton and Man-Made Fibre Underwear adopted on 8 November 1996, WT/DS24/R/Corr.1 and Appellate Body Report United States--Restrictions on Imports of Cotton and Man-Made Fibre Underwear adopted on 10 February 1997, WT/DS24/AB/R., available at http://www.wto.org/english/tratop e/dispu e/cases e/ds24 e.htm, last accessed November 14 2008.
} 
the requirement of the judgements. In particular, some legalized regimes, such as the WTO, authorize "suspension of concessions" under the same agreement or even different WTO agreements where other remedies are unavailable. By having legitimized retaliation, reduced risks of self-help can be achieved.

\section{IV.2 Cons of hard law}

1. Although hard law offers explicit rules which enable state members to predict consequences that are associated with breaking law, this also forces potential law breakers to calculate risks and benefits of not complying with the law. One of the most important cases involving calculating risks and benefits is the Ford's Pinto case. ${ }^{24}$ In this case, one model of car had a design problem which would cause serious car accidents. When determining whether to recall these cars or not, Ford calculated the risks of car accidents, the monetary value they could pay to drivers and the loss if they recalled those cars. Results showed that the risks that they might encounter from litigation were less than the costs if they recalled cars. Ford made the decision not to recall cars. In such cases, if we assume that clear prediction by explicit rules can effectively prevent state members from "misuse of hard law", we are wrong.

2. Another criticism towards hard law is that precise rules make the hard legal system rigid and leave little room for state members to fashion their own way to solve their problems. Thus, hard law can not achieve flexibility as soft law can. As the economic situation changes, it takes time to revise rules as state members are cautious about the steps towards changing rules due to the binding nature of the hard law. As a result, state members cannot adapt their commitments to their particular situations.

${ }^{24}$ G. v. Ford Motor Co., (1981) 119 CA 3d 757. 


\section{Conclusion}

At the international level, international law might utilize different measures other than physical sanctions to maintain state members to make commitment to comply with its rules, but this does detract from the fact that international law is law.

The degree of legalization, either hard or soft, is a choice made by members to pursue their interests and values. Probably, the general goal of legalization, whether hard or soft, is to encourage state members to comply with legal rules and maintain a peaceful environment for their subjects. Both hard law and soft law have their merits. Hard law's explicit rules, binding obligations and neutral third party which renders a binding judgement not only ensure certainty and predictability which encourages members to make commitment, but also have effective settlement measures when conflict arises. Within a hard legalization regime, there are certain remedies to aggrieved parties, such as countermeasures and economic compensations under the WTO. However, hard law remedies are the last resort for aggrieved parties, while consultation and negotiation are sill the priority. This does not mean hard law rules and remedies are not important but show that at the international level, there are other interests such as future economic cooperation which are more important than legal remedies.

Due to soft law's voluntary and non-binding nature, "The international actors often deliberately choose soft forms of legalization as superior institutional arrangement. $" 25$ Under a soft law regime, State members give each other the same amount of mutual respect and this encourages them to make commitment. However, the

\footnotetext{
${ }^{25}$ Abbott \& Snidal, supra, note 22, at 423.
} 
lack of explicit and precise rules cannot ensure certainty and predictability which makes members take an even longer time to get the conflict resolved.

When there are increasing members within a framework for economic cooperation from various backgrounds, certainty, predictability and effective settlement measures appear more preferable. This phenomenon can be seen from the evolution of the GATT. The GATT took a diplomatic approach at the beginning, in which rules were not precise. More importantly, rulings were to be given by the Contracting Parties which included representatives of all contracting parties that were politically presented. As a result, the Contracting Parties could not achieve neutrality. Over the decades, the contracting parties preferred a rule-orientated approach and established the WTO which provides lengthy and explicit binding rules and a neutral Dispute Settlement Body to look into cases. More on the evolution from the GATT to the WTO will be illustrated in the following section. The legalistic approach of the WTO also has a great effect on its members, and the success of the WTO's legalistic approach supports the opinion that international law is law.

The changing approach from diplomatic to legalistic could also been in China. The Chinese government and its people have long been taking soft approach (i.e. mediation) to solve disputes. However, China has been taking a juridical approach to using the WTO measures to protect its rights.

In the following section, the evolution of the GATT to the WTO, and China's changing legalism towards dispute settlement will be analyzed to show the role of hard law in regulating economic transactions. 


\section{Application of the Theories in GATT, the WTO and China}

\section{Introduction}

The WTO, which came into effect in January 1995 is a great achievement of global economic integration based on the rule of law. The agreements of the WTO are effective in ensuring members' compliance, because the WTO contains a more elaborate dispute settlement mechanism. The success of the WTO evidences that international law is law, and it does have the capacity to achieve its goal of maintaining its subjects in order and facilitating development.

The legal achievements of the WTO did not occur suddenly. These achievements were a gradual progressive transformation from the original GATT since 1947. The GATT, was diplomacy orientated agreement. Over years of practice, there was a increasing demand of judicial orientated economic institution. In 1994, the GATT was updated to include new obligations and the WTO was created. This developed over time, and the WTO now takes a more adjudicative approach to dispute settlement.

Since China opened its door for international trade in 1979, China has revised and modified almost all of its laws to further economic development and international trade. China was a signatory member of the GATT, but lost this status due to domestic revolution. It took China 15 years to accede to the WTO. After accession, China is taking a more and more legalistic approach to protect its rights. In the following, the changing nature of GATT to the WTO and China's legal approach in the WTO will be analyzed to discuss the role of hard law in regulating economic transactions. 


\section{The GATT}

\section{I.1 Diplomatic approach and its advantages}

The GATT, was the predecessor of the WTO. Unlike the WTO which takes a judicial approach, the GATT took a diplomatic approach. The reason behind this was the political situation at the time GATT was established. The GATT was set up after the Second World War; states at that time were sensitive about their sovereignty and the political climate was hostile. Thus, a strong adjudicative settlement approach made states concerned about their sovereignty. In addition, at the international level, trade issues intertwine with other issues such as political values and world power balancing. If the GATT 1947 adopted a strong adjudicative dispute settlement, it was foreseeable that it would be difficult to ratify. Thus, a soft approach was more suitable, using consultation and flexible negotiation to facilitate trade issues peacefully.

Unlike the judicial approach which is enhanced by explicit rules and strong adjudication, the diplomatic approach, according to Petersmann, "is characterized by the flexibility of the procedures, the control over the dispute by the parties, their freedom to accept or reject a proposed settlement, the possibility of avoiding "winnerloser-situations." ${ }^{26}$ The diplomatic approach offers several advantages for the GATT contracting parties, one of which is the possibility of flexibility. The losing party could simply block the panel's report and this gives the stakeholders time to implement the panel's recommendation ${ }^{27}$ as they see fit, rather than requiring implementation according to a fixed time.

\footnotetext{
${ }^{26}$ Ernst-Ulrich Petersmann, The GATT WTO Dispute Settlement System International Law, International Organizations and Dispute Settlement_(Boston : Kluwer Law International 1997) at 69.

${ }^{27}$ At the GATT, as of 1952, panels customarily composed of three or five independent expert from third GATT contracting parties became the usual dispute settlement procedure. The panel provided a report
} 


\section{I.2 The Dispute Settlement under the GATT 1947}

The evolution of the GATT dispute settlement mechanism had its roots in its contracting parties. After World War II, states were eager to create an international trade organization (ITO) to remove trade barriers and to rebuild the economy among the Allies. The contracting parties intended to empower the ITO with a strong ability in dispute settlement procedures, however, due to the intense political climate at that time, governments refused to ratify the ITO and the ITO was never established; The GATT was initiated during ITO negotiation, as an interim measure, the GATT was constructed as a diplomatic orientated agreement and was never meant to become a binding legal regime.

The GATT 1947 did not provide for an elaborate dispute settlement mechanism. It contained only two brief provisions relating to dispute settlement: Articles XXII and XXIII. ${ }^{28}$ Neither provision explicitly referred to dispute settlement or provided for detailed procedures to handle disputes.

The GATT 1947 lacked an organizational structure. It did not provide any kind of neutral tribunal that could rule on legal issues. According to Article XXIII, rulings were to be given by the Contracting Parties---the plenary meeting of all the signatory governments. Thus, representatives of the Contracting Parties were politically represented and dispute resolution could not be achieved through neutrality and objectivity.

containing recommendations or rulings had to be adopted by consensus included the disputing parties. More details of the Panel process will be discussed in the following.

${ }^{28}$ The General Agreement on Tariffs and Trade (hereafter GATT) 1947, article XXII: Consultation and Article XXXIII: Nullification and Impairment. 
The language of the GATT is not precise. Within both provisions, there is no explicit reference to "breach of obligations". Rather, in Article XXIII, complaints are based on nullification or impairment rather than breach of legal obligations.

Jurisdiction was not compulsory. In GATT, consensus was required for the contracting parties to establish a panel. This meant that the consent of the defendant had to be obtained before a panel could be established. The panel's report did not have a strong binding force either; it would be adopted only when both parties accepted it. Thus, if the losing party refused to adopt the panel report, the ruling would not take effect and the winning party's rights could not be enforced. Even if the ruling was adopted; there was a "dramatic increase in non-compliance during the 1980 s, notably by the US, the EC and Canada.,29

\section{I.3 Rule-orientated development of the GATT}

The GATT 1947 was drafted in relatively imprecise terms and incorporating a relative low level of obligation and delegation of dispute settlement fell within the soft law category. According to Abbott, as the governments implemented this soft agreement, they could address the non-tariff governmental measures and the internal government regulatory measures that are not directed towards trade effectively. ${ }^{30} \mathrm{With}$ the rule orientated approach, rules are made precise and explicit, level of obligation to implement rules is high and delegation of dispute settlement is more effective. Practices that followed with GATT 1947 showed that contracting parties were more and more adapted to the rule orientated approach. Although the diplomatic approach was more flexible, as more and more members from different backgrounds acceded to the GATT

\footnotetext{
${ }^{29}$ Robert Hudec E., Enforcing International Trade Law. The Evolution of the Modern GATT Legal System. (Salem: Butterworth Legal Publishers1993) at 138.

${ }^{30}$ See Abbott "NAFTA Legalization...", supra, note 20, at 520.
} 
(128 members as of 1994), members needed a legal system that could ensure certainty and predictability. The GATT contracting parties increasingly legalized and codified GATT dispute settlement practice. This trend reflected the need of precise rules and an objective and judicial orientated dispute settlement mechanism to govern trade disputes.

\section{I.3(a) More Objective Dispute Settlement}

One development is a more juridical dispute settlement mechanism. In the early years of the GATT, working parties were set up to assist Contracting Parties with dispute settlement. The working parties included representatives of governments to the dispute and proceeded on the basis of consensus. As a result, the dispute settlement process had a strong negotiating element rather than adjudicative process. What's more, representatives in the working party were politically represented. Thus, working parties could not achieve neutrality and objectivity. However, practice changed. According to Hudec, "the GATT's procedure for third party adjudication of legal claims took a significant step forward in 1952, when it was decided to refer all the legal claims on the agenda of the Seventh Session of the Contracting parties to a body called a Panel on Complaints rather than a conventional working party." ${ }^{31}$ Contrasted to the working party, members of the panel were not representatives of governments but technical experts. Thus, a panel could effectively help the dispute settlement process to achieve neutrality and objectivity.

\footnotetext{
${ }^{31}$ Robert Hudec, "The Role of the GATT Secretariat in the Evolution of the WTO Dispute Settlement Procedure" in Jagdish Bhagwati and Matthias Hirsch, eds., The Uruguay Round and Beyond (Ann Arbor: University of Michigan Press 1998) at 107.
} 


\section{I.3(b) Towards more precise rules}

Another development is the establishment of precise rules. The core provision of dispute settlement is Article XXII and XXIII; however, rules contained in these two articles are ambiguous. According to Jackson,

The article (article 23) is very brief by comparison to most international organization dispute settlement articles, and it has some anomalies. For example, the basis of a "complaint" is not a breach of the legal obligations in the agreement, but is instead something called nullification or impairment. This is a phrase that has always been rather ambiguous in GATT, although an early case in GATT suggested relating this to denial of benefits expected under negotiated concession. ${ }^{32}$

According to Article 23, there is no precise term to determine what constitutes "nullification or impairment", thus, the rule does not condition a complaint on an actual breach of GATT rules. However, over years, practices showed that a breach of a GATT obligation constitutes "nullification and impairment". According to Jackson, in 1962, a panel report made an epic decision that a breach of a GATT obligation would be considered "prima facie nullification or impairment" and since that time a number of other panels have repeated and applied this principle. ${ }^{33}$ Although the GATT dispute settlement was not intended to be a precedent based approach, studies also show that "when one reads the panel reports, one finds considerable reference to prior cases, utilizing them as a sort of precedent.",34

When the evolution of GATT history is explored, we find that instead of a diplomatic approach, the GATT had been taking a more and more legalistic approach. The GATT gradually trended towards a rule orientated approach and departed from a

\footnotetext{
${ }^{32}$ John H. Jackson, The Jurisprudence of GATT \& The WTO (New York: Cambridge University Press, 2000 ) at 124.

33 Ibid.

34 Ibid.
} 
negotiating approach; the GATT trended towards a neutral third party rather than a politics involved working party. All of these evidences show that the GATT has become rule orientated.

Although the ITO had failed to receive approval because of its strong intent of setting up an adjudicative dispute settlement process, after decades of practice under the GATT, members realized the need for a rule-orientated framework. During the Uruguay Round negotiations started from September 1986, several proposals were made to reform the dispute settlement procedures of the GATT among which there was the intent to create a single unified dispute procedure. Another proposal was to make it explicit that there is an international legal obligation upon disputing parties to carry out the adopted results of dispute settlement procedure, and intent to prevent blockage of panel report.

These developments and the move to a more rules-orientated approach for economic cooperation were incorporated in the establishment of the WTO.

\section{The WTO}

The WTO is probably the best example of international hard legalization; it covers a broad range of trading areas that include trade in goods, trade in services, intellectual property and trade-related investment measures. Complex agreements have been reached regarding tariffs, agriculture, standards and safety, textiles, banking, telecommunication, government purchases, intellectual property, food sanitation regulations, anti-dumping, subsidies, etc. Although the WTO agreements are lengthy and

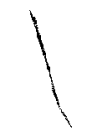


complex as they cover a wide range of activities, fundamental principles are free trade, ${ }^{35}$ trade without discrimination ${ }^{36}$ and predictability. The WTO reflects all the merits of the hard approach such as explicit rules, binding legal obligations and jurisdiction. The heart and central success of the WTO is its Dispute Settlement Mechanism which ensures its members' rights could be enforced.

\section{II.1 DSM-the central success of the WTO as a hard legal regime}

The WTO has evolved from its early diplomatic relation-based origins in the GATT, to become perhaps the best known example of rules-based governance of international economic relations. The most prominent success of the WTO comes from its Dispute Settlement Mechanism. It is the central element in providing security and predictability to the multilateral trading system. The WTO establishes not only rights and obligations to guarantee members' trading right but also enforces their rights through its third party adjudication. In the WTO, negotiations and consultations are encouraged to solve members' dispute and these have been codified in the WTO Dispute Settlement Understanding ${ }^{37}$ (DSU). However, when parties cannot solve their disputes through consultation, they would be referred to the Dispute Settlement Body (DSB), to get a ruling.

\footnotetext{
${ }^{35}$ This is the principle that aims to lower trade barriers which include custom duties and measures such as import bans or quotas that restrict quantities selectively. Upon entering the WTO, protective measures shall be removed. The WTO also takes considerations of developing countries, in order to help the developing countries to protect and promote their own industries, trader barriers could be removed by the set time schedule.

${ }^{36}$ There are two underlying sub-principles: Most Favoured Nation (MFN) and National Treatment (NT). MFN means that countries cannot normally discriminate between their trading partners. Grant someone a special favour (such as a lower customs duty rate for one of their products) and you have to do the same for all other WTO members. NT means that imports be treated no less favourably than the same or similar domestically-produced goods once they have passed customs.

${ }^{37}$ Understanding on Rules and Procedures Governing the Settlement of Disputes" (hereafter, DSU), Annex 2 to the Agreement Establishing the World Trade Organization, available at http://www.wto.org/english/docs_e/legal_e/28-dsu.pdf, last accessed September 212008.
} 
In the WTO, dispute settlement is governed by the DSU which has explicit rules on every step that could take for dispute settlement. In the DSU, WTO members have committed themselves not to take unilateral actions against perceived violations of the trade rules. Instead, they have pledged to seek recourse in the new dispute-settlement system, and abide by its rules and procedures. Members are equal; they enjoy equal rights and equal obligations. Hence, disputing parties, regardless of their economic power, are equal under the WTO. For example, Mexico, as a developing member, is a frequent user of the DSM having initiated 17 disputes. Among these 17 disputes as complainant, the United States were respondent in 7 cases. India, another frequent user of the DSM, filed 17 cases of which 5 cases targeted the EU and 7 cases targeted the United States. ${ }^{38}$ Davey has found that in the last few years, developing countries have made increasing use of the system and have had considerable success in resolving disputes among themselves, as well as against developed countries. ${ }^{39}$

Within the WTO, the Dispute Settlement Body is established to administer rules and procedures and it has the authority to establish panels, adopt panel and Appellate Body reports, maintain surveillance of implementation of rulings and recommendations. The decision made by the DSB is almost automatically binding in practice. Under the WTO, the Panel shall submit its findings in the form of a written report to the DSB which shall set out the findings of facts, the applicability of relevant provisions and the basic rationale behind any findings and recommendations that it

\footnotetext{
${ }^{38}$ The WTO official website, "Disputes by Countries", available at http://www.wto.org/english/tratop e/dispu e/dispu by country e.htm, last accessed October 202008. ${ }^{39}$ William J. Davey. "The WTO Dispute Settlement System: How Have Developing Countries Fared?" Draft, March 8, 2007, at31, available at http://www.luc.edu/law/activities/publications/ilrsymposium/2008sym/davey wto dispute_paper.pdf last accessed September 25, 2008.
} 
makes. ${ }^{40}$ The DSB uses a special decision procedure known as "reverse consensus" or "consensus against" that makes it almost certain that the Panel recommendations in a dispute will be accepted. The process requires that the recommendations of the Panel (or the Appellate Body where disputants appeal) should be adopted "unless" there is a consensus of the members against adoption. This has never happened, and because the nation "winning" under the Panel's ruling would have to join this reverse consensus, it is difficult to conceive of how it ever could. ${ }^{41}$

Prompt compliance with rulings of the DSB is essential to ensure that the members would entrust themselves with the DSM of the WTO. A series of rules on surveillance of implementation have been established in the DSU. The DSU also recognizes there might be difficulty for parties to comply with rulings immediately; hence, both parties would negotiate in order to come up with a certain period of time as cushion. In case the losing party still cannot comply when the reasonable time expires, compensation and the suspension of concessions or other obligations are temporary measures available and could be referred to arbitration to determine the correct level. In any case, the DSB will keep the implementation of adopted recommendations or rulings under surveillance, and any outstanding case will remain on its agenda until the issue is resolved. Consequently, the winning party has a great ability to enforce its rights and this makes the WTO more reliable.

\footnotetext{
${ }^{40}$ Supra, note 37, Article 12, para 7.

${ }^{41}$ Economic Expert.com, "The Dispute Settlement Body", available at http://www.economicexpert.com/a/WTO:Dispute:Settlement:Body.htm, last accessed on October 202008.
} 


\section{II.2 WTO dispute settlement procedure reflects entitlement-based theory}

When we discussed whether international law is law in the theory section, we mentioned D'Amato's entitlement theory. In his theory, both under the domestic and international legal system, subjects have their legal entitlements and their entitlement would be lost if they offend law. At the international level, even if an international law lacks a strong enforcement agency to ensure compliance, state members still have their right to deprive entitlements of the other state member that is at fault. Within that legal regime, such deprivation of legal entitlements will not be regarded as violations of obligations but rather as an effective way of enforcement.

D'Amato's theory about deprivation of entitlement as a way of enforcement holds true under the WTO rules. Under the WTO, each state member has their rights and obligations. As a hard legalization regime, members' obligations are strongly bound. When one state cannot carry out its obligations, various mechanisms are listed in the DSU which include: prompt implementation of panel reports and Appellate Body decisions; reasonable time for implementation, compensation if implementation cannot be achieved and suspension of obligations (countermeasures) as the last resort if compensation cannot be achieved.

Countermeasures in the WTO are of a bilateral nature. They can be taken only by members that were complaining parties. According to Article 22 of the DSU, suspending WTO obligations in relation to another member requires an authorization of the DSB. The complainant is thus allowed to impose countermeasures that would otherwise be inconsistent with the WTO agreement, in response to a violation or to nonviolation nullification or impairment. This is also called retaliation or sanctions. Such 
suspension of obligations takes place on a discriminatory basis only against the member who failed to commit.

According to D'Amato, deprivation of legal entitlement does not have to be the same entitlement that was injured; it might be a different entitlement. Consistent with D'Amato's theory, under the WTO, "the general principle is that the complaining party should first seek to suspend concessions or other obligations with respect to the same sector as that in which the panel or Appellate Body has found a violation or other nullification or impairment" effective to suspend concessions or other obligations with respect to the same sectors or even the same agreement, it may seek to suspend concessions or other obligations under another covered agreement." 43 In the EU Banana case ${ }^{44}$ where the EU was found in violation of the GATT XIII and the General Agreement on Trade in Service (GATS) Ecuador sought and obtained authorization to suspend concessions under other agreements, including TRIPS. In this case, Ecuador's request was a double first in the history of the trading system: the first request for retaliation by a developing country, and the first time approval for cross-retaliation had been sought. ${ }^{45}$

\footnotetext{
${ }^{42}$ DSU article 22. para, 3(a).

${ }_{43}$ Ibid., article 22. para 3 (b) \& (c).

${ }^{44} \mathrm{EU}$ imposed two tariff rate quotas, one for the Africa, Caribbean and Pacific (ACP), the other for non ACP countries; the EU also distributed 30 percent of all import licenses to former British and French Caribbean colonies. In 1997, the WTO panel found that the EU banana import regime was inconsistent with GATT XIII (Non-discrimination) and the 30 percent allocation of import licenses to traditional sellers of ACP bananas was rule inconsistent with GATS non-discrimination rules (Article II). In 1998, EU revised its regime and continued to maintain two tariff rate quotas. Ecuador requested the original panel to examine whether the EU measures were in compliance.

${ }^{45}$ Bernard Hoekman, Aaditya Mattoo \& Philip English, "Development, Trade, and the WTO: A Hand Book" Washington: World Bank 2002, available at http://wwwwds.worldbank.org/servlet/WDSContentServer/WDSP/IB/2004/08/19/000160016_20040819140633/Rend ered/PDF/297990018213149971x.pdf, last_accessed November 13, 2008.
} 


\section{II.3 Why Members Prefer the WTO as a Hard Legal Regime}

The WTO which embraces 153 members on 23 July $2008,{ }^{46}$ is the largest economic regime in the world. All of these members range from tremendously different economic status, from developed to developing, various cultures and different social constructions. Each of them has different orientations towards dispute settlement measures. In accessing into the same economic legal framework, state members were expected to have explicit universal rules on trade rules and enforce them. The WTO was expected to increase trade flows and eliminate trade barriers. According to Petersmann, "during the Uruguay Round of multilateral trade negotiations, one of the reasons for negotiating worldwide rules....was the widely held view among governments that the availability of the GATT dispute settlement system for enforcing rules to render these rules more effective. ${ }^{, 47}$ Over the years, practices that followed from GATT 1947 showed that contracting parties were more and more adapted to the adjudicative approach. Several reasons that illustrate why the WTO takes a hard law approach and these reasons reflect the hard law merits noted in the theoretical section.

\section{II.3 (a) Reasons for hard legalization}

1. By having explicit rules, certainty and predictability of the WTO could be achieved. Article XVI:4 of the Marrakesh Agreement ${ }^{48}$ which establishes the WTO states that each member shall ensure conformity of its laws, regulations and administrative procedures with its obligations as provided in the annexed agreements. In addition, Article XVI:3 also provides that, "in event of a conflict between a provision of

\footnotetext{
${ }^{46}$ The WTO, "Members and Observers", available at http://www.wto.org/english/thewto e/whatis_e/tif e/org6_e.htm, last accessed November 8, 2008.

${ }^{47}$ Petersmann, supra, note 26 , at 63 .

${ }^{48}$ Marrakesh Agreement Establishing the World Trade Organization, available at http://www.wto.org/english/docs_e/legal_e/04-wto_e.htm, last accessed on November 11, 2008.
} 
this agreement and a provision of any of the Multilateral Trade Agreements, the provision of this Agreement shall prevail to the extent of the conflict." ${ }^{49}$ Upon accession, state members are required to implement the WTO laws into their domestic laws and regulations at all levels. Hence, every state member is governed by the same WTO rules and all its domestic rules need to comply with the WTO law. This requirement by the WTO assures the WTO rules are consistent in all state members and traders will not be treated differently in any other states which results in more liberal trade transactions. By embracing certainty and predictability, state members know clearly what are prohibited and the consequences that are associated if the WTO rules are breached. As a result, transparency of the WTO rules is enhanced, the need to bargain over the implementation should be reduced and intergovernmental transaction costs should be reduced

2. By having a more juridical approach to dispute settlement, the WTO produces explicit standardized procedures to achieve objectivity and neutrality to solve disputes. Rulings from the third party become binding. Under the GATT, the panel report containing the findings and recommendations or rulings had to be adopted by consensus. Thus, any contracting party including the party which is the object of the recommendations or rulings could block the adoption of the report. Under the WTO, rather than adopt panel report based on consensus, the WTO Dispute settlement understanding takes a "reverse consensus" which also includes the disputant parties and makes the panel report almost automatically binding.

3. By having legal obligations, members have indicated their willingness to comply and to be bound by the WTO rules. When conducting economic transactions at

\footnotetext{
${ }^{49}$ Ibid.., article XVI:3.
} 
the international level, parties do not only show their willingness to make commitments and take responsibilities when conflicts arise, they also need the same commitments from their partners. Within the WTO, all state members signal their intention to fulfill their commitments upon their accession that they will take measures to comply with and be bound by the WTO laws. The WTO, as a hard legalization institution with strong binding power, satisfied the need of assurance of making commitments of all its members.

\section{II.4 Flexible approach in the hard legalization---WTO}

As we have discussed, there is seldom legalization that is purely hard or soft; legalization is usually a mixture of both. Although the WTO is a prominent example of hard legalization of international economic law, it also respects the merits of a softer approach such as mutual negotiation and flexibility of the soft law. This soft/diplomatic approach can be found from various sections of the WTO:

1. Consultation and negotiation. While the dispute settlement procedure of the WTO resembles adjudication, it also includes a codified and flexible consultation. ${ }^{50}$ Under the procedures of the WTO dispute settlement system, the first step in the dispute settlement process is consultation. Whether the consultation is successful or not, parties should at least attempt to achieve a satisfactory adjustment of their matter. The goal of the consultation stage is to enable the disputing parties to better understand the factual situation and the legal claims in respect of the dispute, with a view to reaching a mutually satisfactory solution of the complaint. The manner how parties conduct consultation is highly flexible and it is up to the parties as long as they consult in good faith. All requests for consultations shall be notified to the Dispute Settlement Body and

\footnotetext{
${ }^{50}$ DSU, article 4.
} 
the relevant Councils and Committees by the Member which requests consultation in writing. ${ }^{51}$ If the consultation fails to settle a dispute within 60 days after the date of receipt of the request for consultations, the complaining party may request the establishment of a panel. ${ }^{52}$

2. The WTO encourages mutually agreed solutions between complaining parties without violating the WTO rules. Under Article 3.6 of the DSU, "mutually agreed solutions to matters formally raised under the consultation and dispute settlement provisions of the covered agreements shall be notified to the DSB and the relevant Councils and Committees, where any member may raise any point relating thereto". One example to show this is the Laver dispute of Japan and Korea in 2002. In this case, a panel was established in March 2005, but on 23 January 2006, Korea and Japan notified the DSB of a mutually agreed solution under Article 3.6 of the DSU and this solution was accepted by the DSB. ${ }^{53}$

3. Implementation of a panel decision can be flexible and a reasonable period of time is negotiable between parties. This reflects the recognition of difficulties that a party might face in order to comply with the judgments. According to Article 21 of the DSU, the party concerned must state its intentions in respect of the implementation of the recommendations within 30 days of the adoption of the panel or Appellate Body report. However, Parties could mutually agree to a reasonable period of time to implement a panel report if it is impractical to implement immediately.

\footnotetext{
${ }^{51}$ Ibid., article 4 para 4.

52 Ibid, article 4 para 7.

${ }^{53}$ Panel Report in Japan-Import Quotas on Dried Laver and Seasoned Laver adopted February 1, 2006, WT/DS323/R and Mutually Agreed Solution in Japan-Import Quotas on Dried Laver and Seasoned Laver adopted on January 27 2006, WT/DS323/5.
} 


\section{II.5 Rationales behind China's Accession to the WTO}

Besides obtaining more economic opportunities in this trading organization by being a member of the WTO, several reasons contribute to China's accession to the WTO. In general, the reasons that influenced China's accession reflect the merits of hard legalization.

\section{II.5(a) Explicit rules of the WTO}

As we discussed in the theory section, hard law offers explicit and precise rules which inform members what is allowed and what is not allowed, thus, hard law ensures certainty and predictability. Established as a hard legalization regime, the WTO offers explicit and lengthy rules which reflect the complicated nature of business activities for members to conduct international trade. In addition, the rules are comprehensive. The WTO has expanded its scope from trade in goods to trade in services and intellectual property.

For China, as well as other state members of the WTO, the lengthier the legal agreements are and the more detailed the rules are, the more understandable "instruction" would appear to state members. As a result, governments know clearly about the nature of their rights and obligations. Hence, the intergovernmental bargaining cost involved in either implementation of obligations or disputes could be reduced. ${ }^{54}$ As set out by Abbott,

More precise rules should provide clearer signals to governments about the nature of their obligations. Such rules should reduce intergovernmental bargaining subsequent to the conclusion of

\footnotetext{
${ }^{54}$ Abbott, "NAFTA...", supra, note 20, footnote 29. Precise rules offer better understanding of both rights and obligations that parties have, hence, parties are more certain on how to accomplish their obligations. However, precise rules may lead to more disputes if parties are certain about their capacity to vindicate a perceived right. However, since obligations are clearly defined, durations of disputes could be shortened.
} 
an agreement. They should reduce the need to bargain over the mechanics of implementation. ${ }^{55}$

Precise rules constrain strategic behaviors. As a communist developing country and a new-comer to the WTO, China is risking being taken advantage of by more powerful state members such as the US. By having precise rules, strategic behaviors could be substantially limited.

Precise rules produce predictability. The private Chinese people need an economic framework whose rules are known in advance which create a stable and secure environment for them to do business. The more precise the agreement, the greater chances of rules of agreements are implemented and enforced by governments, hence, all businessmen are regulated equally. As a result, precise rules offer a greater level of certainty to business planners. Hence, "precise rules help businessmen to reduce risks of doing business and increase the prospects that transactions will be undertaken. ${ }^{956}$

Precise rules also enhance transparency of the WTO. The WTO rules require its members to make their laws, regulations, measures pertaining to or affecting trade in goods, services, TRIPS or the control of foreign exchange to be published and readily available to other members, individuals and enterprises. Thus, all members' trading policies that are prescribed in the WTO are transparent and members know how to deal with their trading partners.

\section{II.5(b) Binding obligation to show commitment}

Another feature of hard law, as discussed in the theory section, is binding obligation. Generally speaking, the binding nature of hard law not only makes the law

\footnotetext{
${ }^{55}$ Abbott, "NAFTA...", supra, note 20, at 526.

${ }^{56}$ Ibid., at p529
} 
itself reliable but also effectively encourages members' commitments. Since the WTO is framed as a hard legal regime, members are bound by the WTO rules. although China is one of a few communist countries and its economy is a market economy with socialistic characteristics. The WTO offers universal rules that require all state members to remove trade barriers to increase trade liberalization. Thus, the binding obligation of the WTO rules assures China that all other members will make efforts to fulfill their obligations.

On the other side, by acceding to a hard law framework, China shows its great willingness to be bound by WTO rules and make commitments accordingly. Foreign traders need China to trade within the same legal regime to achieve certainty and predictability because of China's distinct historical background. China is one of a few communist countries that have communist ideology, social structure and legal system. The current economy with socialistic characteristics is also different from that of most Western economies. One of the examples is state intervention. Although China claimed that it switched from a planned economy to a market economy with socialistic characteristics, state intervention still applies when the state government sees the economic situation needs government control.

In addition, China's legal system has been intertwined with administrative manipulation which is different from Western legal systems. At lower government levels, local government officials may exercise their administrative powers to the convenience of business by not strictly applying the law or even allowing avoiding compliance with the law. In order to obtain this convenience from local officials, businesses need to develop their networks with local officials and this leads to bribery and corruption. In such cases, the Chinese law lacks certainty and predictability. 
Due to these concerns, there is a need to ensure other members of the WTO that China will make commitment in international economic transactions. Accession to a binding hard legal regime, is one of the best ways to show one's willingness to be part of the legal framework. By entering into the WTO, the entire custom territory of China including all levels of governments are bound to the WTO rules to regulate the economic sector. The WTO obligations will be implemented, trade barriers will be removed according to a fixed schedule; regulations and laws will be furthered to be compatible with the WTO rules. In the event of conflicts, the WTO' dispute mechanism will take measures to solve problems. As a result, foreign traders have more confidence in doing business with Chinese trade is under the same legal regime.

\section{China's Legal Development Before and after Accession}

China's legal development reflects its ongoing evolution from soft legal approach to a hard approach. The Chinese traditional legal thinking takes a soft approach since it has been influenced by Confucianism for a thousand years. Confucianism takes a soft approach in regulating people's behaviors which encourages all members of the society to build up a harmonious environment, and Confucianism emphasizes dispute avoidance and resolving conflict though informal personal contact. Confucianism does not have explicit rules but only guidelines to direct people's behaviors. Confucianism rules are not binding; if members act against Confucian rules, they would only be morally condemned. If a conflict arises, people are encouraged to solve it in informal ways such as negotiation to avoid confrontation. Since the 1979 Open Door Policy, the Chinese legal system has been taking a hard law approach and modified a number of laws to 
promote legal certainty and predictability. The achieved certainty and predictability has resulted in public confidence in official justice. As a result, litigation is becoming the principal means to solve economic disputes. Hence, the Chinese are adapting to take a hard law approach and the influence of the dispute avoidance has been reduced by a great extent. To examine to what extent the WTO rules are amiable to the Chinese economic relationship, an illustration of Chinese legal development from a soft orientated approach to a hard approach will be examined in the following:

\section{III.1 Guanxi----informal personal contact}

Generally speaking, Confucianism is a Chinese ethical and philosophical system developed from the Chinese philosopher Confucius. It is a complex system of moral, social and political thoughts that have been governing Chinese behaviors for centuries. Confucianism is the most influential ideology in China as well as other Asian states such as Korea and Japan. It promotes a harmonious environment in which people have a good Guanxi (informal personal relationship) with others and it promotes conflict avoidance which is also a strategy to obtain good Guanxi.

To Chinese, Guanxi means good relationships/networks between one another. It could be individual or organizational relationships, usually the nature of Guanxi is informal. Guanxi is not a unique feature of the Chinese society but exists in every society. However, unlike the Western network which includes all personal connections you have, the Chinese Guanxi in particular means a strong background and a relationship which could bring benefits. Most of time, Guanxi means knowing and maintaining a good relationship with a person who has a superior position or one who has scarce resources. Usually, Guanxi refers to a good relationship with government officials. 
If one has a Guanxi, one could accomplish his goal much easier than those who don't. What is crucial for Chinese is that they live on their Guanxi and their quality of life largely relies on their Guanxi. If there are corporations competing for an order, the one which has a better Guanxi has a better chance to get the order. Thus, when foreign corporations initiate their business, they need to take a great consideration of hiring people who have strong Guanxi. These people might not have strong technical ability but their Guanxi with government officials or people who hold scarce resources could make the corporation run more smoothly.

One example which shows the importance of Guanxi is the AVON case. AVON initially failed to convince the central government of the workability of its direct marketing method. AVON later obtained the assistance of David Li, the head of Hong Kong's Bank of East Asia. Li had cordial Guanxi with the Chinese government and he successfully introduced AVON to the Bureau of Light Industry in Southern China. ${ }^{57}$

Guanxi, to a large extent, reflects the traditional attitudes towards bureaucracy and the rule of man or administrative intervention of economic and legal affairs in China. After being dominated by Agriculture society for thousands of years, powers of officials and the royal family were strengthened by instilling the ideology of unconditional obedience. This ideology, known as Confucianism, was adopted by every dynasty due to its usefulness for domination. The good part of this ideology is that it encourages people to obtain good education in order to be a good bureaucrat, which has long been a very powerful and beneficial position. However, this good part was greatly exploited by people who valued personal benefits such as potential financial income and

${ }^{57}$ Eric Tsang W.K., "Can Guanxi Be a Source of Sustained Competitive Advantage for Doing Business" (1998) 12 no 2 Academy of Management Executive 64 at 65. 
family glory over actual duty. (i.e. chances to know high rank officials, thus stronger Guanxi).

Guanxi also reflects the strong influence of rule of man in traditional Chinese culture. In both rule of man or rule of law, rules are made by people. The difference between them is that under the rule of law, rules are interpreted by judiciary whereas interpretation of rules is intervened by non-judicia factors under the rule of man. The basic ideology of the Confucianism is "obedience, if the emperor wants one to die for no reason, one has to die." ${ }^{58}$ The higher the rank of an official, the greater their capacity to interpret and execute law by their own will, thus, law was undermined by the political power of the officials. Within this traditional culture, the prominent benefit for officials is that they interpreted law and their interpretation received obedience. As the result, individual power is promoted and the individual could define what is permissible in a given context at a particular time. According to Yehung, "the Chinese authority forced McDonald's to relocate in Beijing to accommodate real estate development by Hong Kong Billionaire Li Ka Shing who has good connections with high rank officials in Beijing. ${ }^{59}$ It is easy to understand why guanxi is important.

The influence of guanxi is becoming weaker; the Communist Party has been taking a juridical approach and encouraging people to recognize the rule of law and equality of individuals. Since 1979 , a number of laws have been produced to call for people's reliance on law to solve conflicts. After China's accession to the WTO, all laws that relate to trade are made transparent and with conformity to the WTO rules. Thus,

\footnotetext{
${ }^{58}$ The unconditional obedience also includes a child's obedience to his father and wife's obedience to her husband.

${ }^{59}$ Irene Y.M Yeung. \& Rosalie L. Tung, "Achieving Business Success In Confucian Societies: The Importance of Guanxi (connections)" (1996) 25no 2 Organization Dynamics, 54 at 60.
} 
trade laws in China are achieving certainty and predictability which eliminates businessmen's reliance on guanxi. The juridical approach not only encourages people to respect laws but also helps foreign investors without having to seek guanxi. As the result, other members of the WTO would be assured that Chinese and their government will refer to the WTO rules to solve disputes.

\section{III.2 Dispute avoidance}

Since Confucianism promotes a harmonious environment, it encourages people to solve conflicts through soft ways such as negotiation rather than confrontation. At the individual level, it views disputes as a signal of relationship break-up; at the international level, it views disputes not purely as legal issues but also intertwined with other reasons (i.e. political/economic). In addition, after litigation, both the winning party and losing party will be criticized. The winning party will be criticized for bringing the case aggressively to the court and the losing party will be criticized for its legal wrongfulness. As a result, Confucianism encourages people to try to find ways to save

not only their own faces but also counter--party's faces. Rather than litigation, it encourages people to solve their problem through informal ways. Hence, dispute is seen as the last resort for resolving problems between parties.

Because of the Confucian culture and its implications of guanxi and dispute avoidance, it is not hard to understand why the WTO members were concerned about doing business in China. Hence, it is a great concern that the WTO rules be implemented well in China. The Chinese legal development shows that China is taking a juridical approach both domestically and internationally. 


\section{III.3 Legal Mobilization in China-Towards a Legalistic Approach}

It has been well recognized that the soft legal approach of Confucianism still plays an role in governing people's behavior at present, and helps solving conflicts through informal ways. However, The analysis below shows China's legal system is becoming more rule-orientated and compatible with international law; and that the juridical approach is gaining popularity both internationally and domestically.

As well as taking consideration of the Chinese traditional culture, one must consider the legal mobilization in China. Although Chinese Confucianism has influenced the Chinese for thousands of years, one should also note that laws especially business laws are not absent from Chinese history. According to Scogin, "the Chinese conception of contractual obligation is the product of a lengthy historical evolution."60 Although Confucianism preferred negotiation and mediation, the recognition of law had never been undermined and it remained as the last resort. "There have been excellent studies of the abundant records of contracts in late imperial China, especially those of the nineteenth century."

Besides the long history of law in China, there has been a legal reform in China after the People's Republic of China (PRC) was established in 1949, especially after the 1979 Open-Door policy which reopened China to facilitate international trade and investments to promote the Chinese economy. The opening up has brought more and more foreign investors to China who do not have any guanxi at all but only rely on the legal system. Thus, there is a need to frame the Chinese law as hard law compatible with

\footnotetext{
${ }^{60}$ Hugh T Scogin, "Between Heaven and Man: Contract and the State in Han Dynasty China". (1990) 63 no 5 Southern California Law Review 1326 at 1327.

${ }^{61}$ Ibid., at 1327.
} 
the international laws to achieve certainty and predictability. As a result, China's legal reform has produced profound changes. According to Pei,

Within China, the Changing legal institutions have begun to play an increasingly important role in governing economic activities, resolving civil dispute, enforcing law and order, and setting the boundaries between the power of the state and the autonomy of society. Outside China, these changes have elicited increasing attention from Western government and scholars. Indeed, promoting the rule of law has gained a new status as part of the West's grand strategy of engagement with China and promotion of human rights and open society in that country. ${ }^{62}$

\section{III.3(a) Development of Commercial Law/Judiciary in China}

Two important periods for legislation revision exist, one from 1979 to 2001(the year which China accessed to the WTO) and the other from 2001 to the present. Along with the modification of commercial laws, the judiciary has also undergone changes to respond to the need for competent interpreters of law. Both periods of law production and judiciary development aimed to provide explicit and precise rules and neutral competent third party dispute resolutions to guide economic transactions.

\section{Massive law production: 1979-2001}

After the Open-door policy was established as a national policy in 1979 , the government found that most of the laws were outdated, not to mention there were few laws related to economic practice, especially international economic transactions. In 1987 , 111 of 134 laws passed before 1979 were announced as invalid for a variety of reasons. ${ }^{63}$ During the period from 1978 to 2001, China's legislature---National People's Congress (NPC) passed 165 major laws, amended 32 laws, and issued 88 resolutions. It is worthy

\footnotetext{
${ }^{62}$ Minxin Pei, "Does Legal Reform Protect Economic Transactions? Commercial Disputes In China" in Peter Murrell Assessing the Value of Law in Transition Economies (Ann Arbor: University of Michigan Press, 2001) at 180.

${ }^{63} 11$ were annulled by new laws, 41 were superseded by new laws, 29 ceased to be enforced or applicable due to changes in circumstances and 30 had expired.
} 
to note that one third of all legislative output consisted of laws governing economic practices. $^{64}$ This great productivity of economic law reflected that the incentive of the Open-door policy was economic development. To trade globally and make itself a credible trading partner, China had to reform its strong socialistic commercial law and incorporate new concepts from Western society to further its international trade. During this period, the new contract law was revised in 1999; "in drafting the new Contract Law, the Chinese legislators referred extensively to the UNIDROIT principles of International Commercial Contract." ${ }^{965}$

The massive production of law during this period also reflects China's preparation for accession to the GATT. It was not a coincidence that China revised most of its laws and started to establish and adopt new laws in 1987, the year in which China submitted its first application to retrieve its status in GATT.

\section{Law production: 2001--present}

After accession to the WTO in 2001, to conform with the WTO agreements, according to Kong, "current laws and regulations pertaining to or affecting trade in goods, services, etc., need to be drastically changed, revised or enacted." 66 Various laws and regulations that aimed to fulfill obligations of the WTO have been published. According to the 2006 Report to Congress on China's WTO compliance by the United States Representative, "during the transition period, China has repealed,

\footnotetext{
${ }^{64}$ Pei, supra, note 62 , at 184.

${ }^{65}$ Yuqing Zhang \& Danhan, "The New Contract Law in the People's Republic of China and the UNIDROIT Principles of International Commercial Contract: A Brief Comparison", available at http://www.unidroit.org/english/publications/review/articles/2000-3.htm, last accessed Oct 10, 2008.

${ }^{66}$ Qingiiang Kong, China and The World Trade Organization, A Legal Perspective (New Jersey:World Scientific Publishing Co. 2002) at 61.
} 
revised or enacted more than one thousand laws, regulations and other measures in an effort to bring its trading system into basic compliance with WTO standards, China has also taken steps to implement numerous specific commitments pursuant to schedules set forth in its WTO accession agreement." 67

The WTO law, as a hard law, needs to be implemented into the domestic law which means all Chinese domestic laws that are trade-related need to be consistent with the WTO laws. One example is in agriculture. China faces significant problems related to the SPS compliance ${ }^{68}$ because of increasing concerns about safety of the Chinese food products. According to Dong and Jesen, “although China's export mix varies from country to country, there are common SPS problem with Chinese agriculture...one of the reasons that cause this problem is no sound laws for food safety and inspection." ${ }^{69}$ Since accession to the WTO, the Chinese government has been working to establish regulations to meet the WTO standard. According to Dong and Jesen, “under China's recent established National Agricultural Standards Development Plan for 2003-2005, the government has focused on reducing residue levels and increasing inspection methods for chemicals, veterinary drugs, and feed additives."70

In addition, according to the "Protocol On the Accession of The People's Republic of China", China undertakes that only those laws, regulations and other

\footnotetext{
${ }^{67}$ United State Trade Representative. "2006 Report to Congress on China's WTO Compliance", avaiable at http://www.ustr.gov/assets/Document_Library/Reports_Publications/2006/asset_upload_file688_10223.pdf $\mathrm{p3}$, last accessed on September 19, 2008,

${ }^{68}$ Agreement on the Application of Sanitary and Phytosanitary Measures, which is one of the agreements under the WTO to improve the human health, animal health and phytosanitary sitation in all members. available at http://www.wto.org/english/docs_e/legal_e/15sps_01_e.htm Last accessed, last accessed on Oct 23, 2008, ${ }^{69}$ Fengxia Dong \& Helen H.Jensen, "The Challenge of Conforming to Sanitary and Phytosanitary Measures For China's Agricultural Exports", MATRIC Working Paper 04-MWP8, available at Http://www.card.iastate.edu/publications/DBS/PDFFiles/04mwp8.pdf last accessed at 8, last accessed September 20, 2008.

${ }^{70}$ Ibid.., at 8.
} 
measures pertaining to or affecting trade in goods, services, TRIPS or the control of foreign exchange that are published and readily available to other WTO members, individuals and enterprises, shall be enforced. These laws shall be made available to WTO members upon request. Since the Chinese economy is labelled as a market economy with socialist characteristics and the default economy under the WTO is a market economy, by conforming to the WTO laws and making the Chinese laws transparent, foreign investors feel more confident in the Chinese legal system.

\section{Judiciary development}

Within a hard legalization regime, a neutral and competent third party is critical to give binding decisions. Besides rule development in the Chinese commercial law, another noticeable development can be found in the judiciary. The Chinese judiciary processes have always been criticized as non-transparent, and judgments are criticized as lacking legal reasoning and analysis. These problems are well recognized. In order to strengthen the transparency of the judgment document, the Supreme People's Court set up the Chinese Supreme People's Court's judicial website on foreign commercial and maritime disputes in 2001 to publish maritime and commercial case judgment documents involving a foreign element. ${ }^{71}$

Another development, in order to guide courts at all levels in applying laws correctly and to increase judges' professionalism, is the Supreme People's Court Notice on People's Courts' Application of Law in Handling Commercial Cases Involving Foreign Elements issued on 21 July 2003 (See Appendix 1). As well, to raise professionalism, judges are held responsible for their wrongfully adjudicated cases. In

\footnotetext{
${ }^{71}$ The foreign elements includes disputes arising from Hong Kong, TaiWan and Macao.
} 
addition, according to Kong, major cities recruit law professors from well-known universities and send their existing judges abroad to further their professionalism. Sending judges abroad to study and experience applications of the WTO rules became more popular after China's accession to the WTO since China has several disputes with its WTO members. ${ }^{72}$

\section{III.3(b) Legalistic Approach Both at Individual Level and International Level}

Not only is the Chinese legal system becoming more and more ruleorientated, the individual and international practice also show a juridical approach in which parties take law to protect their perceived rights.

\section{Individual level}

As the Chinese legal system is more and more complete and mature, together with the Western ideology of "role of law" and "defend one's rights", confidence in Chinese law is increasing. The obvious evidence of this increasing confidence is the rising of people's increased usage of litigation to protect their rights.

According to Pei, data on rates of litigation show a dramatic increase in commercial, civil, and administrative lawsuits since the early 1980s'. (See Appendix 2) Compared with alternative dispute methods, litigation has become the principal means of dispute resolution in China since the late 1970s. From the mid-1980s, the number of cases resolved by alternative dispute methods are relatively unchanged (about a million cases a year). ${ }^{73}$ The rising litigation rate shows people's confidence in the Chinese legal system. Not only are people in the developed economic areas more confident in the legal

\footnotetext{
${ }^{72}$ Kong, "China and WTO....", supra, note 66, at p79.

${ }^{73}$ Pei, supra, note 62, at 184.
} 
system and bringing litigations to the courts, but people in developing provinces are generally bringing more cases to the court.

In the end, the legal mobilization of modifying laws and the increased professionalism of the judiciaries reflect China's need for hard law. As China is having more and more economic transactions with foreign states, people need a legal framework which has explicit rules to help parties to know what actions are accepted, binding obligations to encourage parties to fulfill their obligations and a competent party to interpret relevant laws to make appropriate rulings. Hence, the soft law approach which lacks certainty and predictability could not satisfy people's needs. As the result, China is taking a juridical approach.

\section{International level. Comparison of Chinese practice at the international level} before and after accession to the WTO

Before accession to the WTO, China's approach to international law reflected the Confucian approach and mistrust of international law. This is lustrated by China's participation in the UN's International Court of Justice.

The People's Republic of China has occupied its seats in the UN and membership of the UN Security Council since Oct 25, 1971. The International Court of Justice (ICJ) is the principal judicial organ of the United Nations (UN). All members of the UN are de facto parties to the Statute of the ICJ. ${ }^{74}$ "The court's role is to settle, in accordance with international law, legal disputes submitted to it by states and to give advisory opinions on legal questions referred to it by authorized UN organs and

\footnotetext{
${ }^{74}$ Charter of the United Nations, article 93.1.
} 
specialized agencies. ${ }^{, 75}$ The jurisdiction of the ICJ is not compulsory but based on the consent of the state to which it is open. The process of the ICJ is adversarial, each party needs to prepare proofs and evidence to the court and the court needs to make judgment based on facts and law. ${ }^{76}$ China has been a reluctant user of the ICJ and it has had no cases before the ICJ.

One reason contributing to China's reluctance in bringing cases before the ICJ is the adversarial process in the ICJ. Adversarial systems are based on the belief that pitting two adversaries against each other, with each interested in presenting its version of the truth, is the best way for a decision maker to determine the probable truth. ${ }^{77}$ This ideology of the adversarial system is against the principle of Confucianism which disciplines people to facilitate harmony and resolve conflicts through negotiation. Not to mention that bringing a dispute against another state is regarded as an obvious signal of political break-up.

Another reason contributing to China's reluctance in bringing cases before the ICJ is its mistrust of international law. China has perceived that international laws were framed based on Western values and manipulated by the Western political powers to achieve their best ends. ${ }^{78}$ As a result, its participation at the international level was

\footnotetext{
${ }^{75}$ International Court of Justice, "The Court", available at http://www.icj-cij.org/court/index.php?p1=1 last accessed 8 November, 2008.

${ }^{76}$ Article 52, after the court has received the parties' proofs and evidence within the time specified for the purpose, it may refuse to accept any further oral or written evidence that one party may desire to present unless the other side consents.

Article 53 (2) The court must, before doing so, satisfy itself, not only that it has jurisdiction in accordance with Article 36 and 37, but also that the claim is well founded in fact and law.

${ }^{77}$ Herbert D. Bowman, "The Adversarial System-Origin and Practice in the United States with a comment on Recent Changes in Chinese Criminal Procedure" (2004) 1(1) US-China Law Review. 43 at 43. ${ }^{78}$ According to Eric A. Posner in his article "the Decline of the International Court of Justice" University of Chicago Law and Economics, working paper No 233, States represented on the first court (ICJ) belonged to the bloc of major western powers or dominated by them either because of their regional or postcolonial status. While the eastern bloc was absent, the advanced western states dominated the docket
} 
characterized by doubt, mistrust and reservations from the 1950s to the 1970s (the Cold War Period). Thus, according to Gao, "in order to cherish its hard-won sovereignty, it generally shuns the jurisdictions of international tribunals, even though some of its citizens have served or are serving as judges in these tribunals." $" 79$

Although China has been a reluctant participant in the ICJ, it tried very hard to access to the WTO, and this reflects China's increasingly legalistic approach. As noted above, to facilitate economic development, China did a massive revision of domestic laws to be compatible with the international standards and had various bilateral agreements with trading partners. With the continuing rapid expansion of China's participation with international institutions and its involvement in the process of globalization, China realized the benefits an effective dispute settlement mechanism could bring. The WTO, as the largest hard economic legal framework, provides a range of measures from consultation to adjudication which could protect members' rights to the largest extent.

One might wonder how China protected its rights before accession to the WTO. In Kong's book, China and the WTO, A Legal Perspective, he discussed several cases between China and its trading partners before its accession in 2001 and concluded that the common elements among the different approaches to the various trade disputes were as follows. The first one is that China deems consultation as an important strategy towards trade dispute settlement. The second one is China showed its inclination to resort to retaliation where its trade partners impose restrictions on its exports in a way it deems

until the 1960s, available at http://www.law.uchicago.edu/Lawecon/WkngPprs_226-50/233.eap.icj.pdf, last accessed November 18, 2008.

${ }^{79}$ Henry Gao, "Taming the Dragon: China's Experience in the WTO Dispute Settlement System", (2007) 34(4) Legal Issues of Economic Integration, 369 at 376. 
unfair. ${ }^{80}$ These common elements show that although China has been influenced by Confucian culture which preaches dispute avoidance, it does not avoid disputes in practice to defend its rights. These retaliatory measures could be explained by the fact that China did not have effective multilateral mechanisms to deal with disputes. Due to the lack of multilateral mechanisms, the most effective measure is to take retaliatory actions. However, it is unfair to say that China abused retaliatory measures. Rather, according to Kong, when China has disputes with its partners, it interpreted the agreement strictly. What's more, "China may be reluctant to yield to the claims of its trade partners; on the other hand, China is a good fighter for its presumed legitimate interests and will predictably begin using the WTO rules to protect its perceived interest." $^{, 81}$

\section{China's Approach Towards the WTO Dispute}

\section{Settlement Mechanism}

As well as taking a hard law approach within the domestic framework, China is also taking an adjudicative approach to solve conflicts under the WTO. Initially, China was not an active user of the WTO measures. Until the beginning of 2007, China was a claimant in only one case and was a respondent in only four cases. However, China's participation in the dispute settlement process is increasing. As of September, 2008, China was a claimant in three cases and a respondent in eleven cases. Is this increasing use of the DSU indicating China's aggressive legalism under the WTO? Aggressive legalism is defined as "a conscious strategy where a substantive set of

${ }^{80}$ Kong, supra, note 66 , at142.

81 Ibid., at133. 
international legal rules can be made to serve as both shield and sword in a trade dispute among sovereign states." ${ }^{.82}$ This is the strategy where a government utilizes rules of the WTO to counter what a member state's government deems to be the unreasonable acts, requests and practices of its major trading partners. Experience of the WTO dispute settlement mechanism shows that major trading powers such as the US and the EU are also major users of the WTO dispute settlement system. Will China as a new member of the WTO also adopt this aggressive legalism and be a new frequent user of the WTO dispute settlement system?

\section{IV.1 Reluctant User to Aggressive User}

China has been largely and conspicuously absent from major WTO litigation in the initial period following its 2001 accession. According to Brown, "just as China has been infrequently on the offensive in WTO litigation; it has also infrequently had to defend itself from foreign challenges until 2006." ${ }^{83}$ In 2004 , The US filed a complaint on "Value-Added Tax on Integrated Circuits" and China agreed to amend or revoke the measures at issue. Hence, this dispute was resolved through consultation. Nevertheless, there are increasing signs that this grace period may be coming to an end which may foreshadow a major shift in China's role in formal dispute settlement going forward. This is especially true in the US-China Auto Parts Case in which the WTO upheld that China did violate the WTO rules and China appealed to the Appellate Body. Until the beginning of 2007, China was claimant in only one case and was respondent in only four cases. Then, in September 2007, China lodged its first independent formal

\footnotetext{
${ }^{82}$ Saadia M.Pekkanen, "Aggressive Legalism: The Rules of the WTO and Japan's Emerging TradeStrategy" (2001) 24 no 5 The World Economy 707 at 708.

${ }^{83}$ P Chad Brown, "China's WTO Entry: Antidumping, Safeguards, and Dispute Settlement" Brandeis University August 2007, available at http://www.nber.org/books in progress/china07/bown8-13-07.pdf, last accessed on 30 October, 2008.
} 
complaint against the US. ${ }^{84}$ On 19 September19, 2008, China requested consultations with the US regarding Definitive Anti-Dumping and Countervailing Duties on Certain Products from China ${ }^{85}$. As of September 2008, China was a claimant in three cases, a respondent in eleven cases. (See Appendix 3)

These figures show that China has taken a more and more legalistic approach in the WTO. However, this more aggressive legalism should not be viewed negatively but as an indication of China's adjustment of itself in the hard legalization regime of the WTO.

Several reasons could be given for China's transformation from a reluctant user to an aggressive user.

1. The initial reluctance to use the DSM reflects Confucian culture which favours dispute avoidance. Confucianism encourages all parties to solve their conflict through a negotiated way to build up a harmony environment. More importantly, Confucianism views disputes as a signal of break up. Guided by this ideology, China was a quiet member of the WTO. Proper understanding of the nature of the WTO dispute settlement system contributes to China's aggressive legalism. After years of practice in the WTO, China has observed that "requests for conciliation and the use of the dispute settlement procedures should not be intended or considered as contentious acts. ${ }^{, 86}$ As a result, China realized that initiating a case or being a respondent of a case are not signals of political or economic break up among parties but merely ways of solving problems.

\footnotetext{
${ }^{84}$ Request for Consultation in United States-Preliminary Anti-Dumping and Countervailing Duty Determinations on Coated Free Sheet Paper from China was received on 14 September, 2007.WT/368/1

${ }^{85}$ Request for Consultations in United States-Definitive Anti-Dumping and Countervailing Duties on Certain Products from China, received on 19 September, 2008. WT/DS379/1.

${ }^{86}$ DSU, article 3 para10.
} 
2. This trend also reflects a better knowledge of the WTO rules and confidence in utilizing the DSM. As a system based on hard legalization, the WTO offers explicit rules. After having a good understanding of the rules, China knows what is allowed, what is prohibited and whether its counter-trading partners' actions are consistent with the WTO rules or not. According to Gao, Japan and Korea were also reluctant users of the WTO measures in their early years. Along with good knowledge of the WTO rules and victories in disputes under the WTO, they became more aggressive. ${ }^{87}$ One way for China to gain knowledge of the DSM is through its past dispute experience. Although China does not have much experience at the WTO, China learns from observing as a third party. According to Brown, China has been extremely active in observing the WTO dispute settlement process through third party observation. ${ }^{88}$ It is believed that third party observation would give China opportunities to observe how. various disputes are settled under the WTO. According to Bown, "China has chosen to participate in many different types of dispute over a range of traded products"89

3. This trend also reflects the Chinese government's positive attitude towards utilizing the DSM. Years after China's pursuit of a domestic rule-orientated legal framework since 1979 , both the government and its people are becoming confident in taking legal actions to solve conflicts. Different from initial dispute avoidance, the Chinese Government officials have made statements indicating that China is prepared to make use of the WTO dispute settlement mechanism. At a press conference hosted by

\footnotetext{
${ }^{87}$ Henry Gao, "Aggressive Legalism: The East Asian Experience and Lessons for China", available at http://www.worldtradelaw.net/articles/gaolegalism.pdf, last accessed October 14, 2008.

${ }_{88}$ Brown, supra, note83, at36.

89 Ibid.
} 
the State Council Information Office on May 30, 2005 to give updates on the textile issue,

Mr. Bo Xilai, Minister of Commerce of the People's Republic of China, stated:

On your third question about the possibility of bringing the case to the WTO dispute settlement mechanism, let me make three points: First, the DSM is a legitimate right that China is entitled to. We will use this right when it is time to do so. Second, bilateral negotiations have advantages of them (sic) own. However, they also easily lead to a situation where each party claims to be right and no solution is possible as there is no judge. Third, sometimes one-to-one talk is less effective than a multilateral mechanism, whereby the public can judge who is right and who is wrong. ... Of course, whether and when we will resort to the DSM is completely up to the Chinese side. ${ }^{90}$

Further, while affirming that China prefers to resort to consultation for settlement of trade friction with its trade partners rather than to the World Trade Organization, Mr. Bo has stated, "it is a normal practice to solve some trade frictions within the framework of the WTO mechanism for dealing with trade disputes", and, "if the consultations fail, we would respect the choice of our trade partners and resort to the WTO mechanism." ${ }^{91}$ In commenting on the disputes brought by the US against China on TRIPS, the Chinese Vice-Premier Wu Yi, made comments that "the Chinese government is extremely dissatisfied about this and will proactively respond according to the related WTO rules and see it through to the end." 92

\footnotetext{
${ }^{90}$ The Chinese Embassy. "Transcript of Press Conference by Mr. Bo Xilai, Minister of Commerce of the People's Republic of China", May 30, 2005, available at http://gr.chineseembassy.org/eng/xwdt/t200344.htm, last accessed September 24, 2008.

${ }^{91}$ Ministry of Commerce, The People's Republic of China "Minister: China prefers to solve trade friction through consultations", Monday, March 12, 2007, Posted: $01: 27$ BJT(1727 GMT) xinhua, available at http://english.mofcom.gov.cn/aarticle/subject/lhsessions/lanmua/200703/20070304450630.html last accessed on September 24, 2008.

${ }_{92}$ China Daily. "Wu: US Piracy Case Will Harm Trade Ties". 24 April 2007, available at http://www.chinadaily.com.cn/china/2007-04/24/content_858638.htm, last accessed Oct 252008.
} 


\section{IV.2 Cases under the WTO}

The following three cases show China's approach towards the DSM from diplomatic to legalistic under the WTO.

\section{The US-China Steel Case ${ }^{93}$}

Right after China's accession to the WTO, China filed a dispute with seven other co-complainant countries in a formal challenge to the U.S. use of a safeguard to restrict steel imports in 2002. The quick move of China using legal tools to file a dispute after its accession surprised many observers and this was also seen as a sign that China would play an active role in WTO dispute settlement.

This case is the first step that China took towards using the WTO rules to solve its trading issues with other members and this first step was cautious. Rather than file a dispute all by itself, China joined with seven other co-complaints and one of the cocomplaints was the EC which is a frequent user of the WTO dispute settlement system, and other co-complaints included Korea, Japan and Australia, also major traders in the WTO. By co-operating with these major trading powers, China was under less pressure either domestic or international of losing the case. On the other side, China also wanted to show that it would utilize legal tools to protect its interests.

\footnotetext{
${ }^{93}$ Panel Report in United States-Definitive Safeguard Measures on Imports of Certain Steel Products adopted on July 11 2003, WT/DS259/R and Appellate Body Report in United States-Definitive Safeguard Measures on Imports of Certain Steel Products adopted on November 10, 2003, WT/DS259/AB/R.
} 


\section{Value Added Tax on Integrated Circuits ${ }^{94}$}

The first case in which China was a respondent is the "Value added tax on Integrated Circuits". On 18 March 2004, the United States requested consultation with China concerning China's preferential value-added tax for domestically-produced or designed integrated circuits. This case was settled at the consultation stage. On 5 October 2005, China and the US informed the DSB that they were in agreement that the terms of the agreement had been successfully implemented, and thus they had agreed that a mutually satisfactory solution had been reached to the matter raised by the US.

This dispute was settled promptly, one reason contributing to this prompt settlement was the Chinese Confucian culture. Before the US made the request to the DSB for consultation, the US and China had undertaken several bilateral negotiations. According to the Chinese Confucianism culture, the sudden legal action brought by the US made China think the relationship between the US and China might be broken. ${ }^{95}$ In order to avoid political embarrassment, China would rather settle through a negotiated way than going through the WTO dispute settlement procedure.

It is argued that if Confucianism really affects China's orientation towards the WTO dispute settlement system, China would not have sued the US in the steel case. However, the conditions of the two cases are different. According to Gao, in the Steel case, the US was urging complainants to bring the case to the WTO for settlement; while in Value Added case, the US brought the case to the WTO in the process of bilateral

\footnotetext{
${ }^{94}$ Request for Consultation in China-Value-Added Tax on Integrated Circuits was received on March 18,2004,WT/DS309/1 and Mutually Agreed Solution in China-Value-Added Tax on Integrated Circuits adopted on October 6, 2005.WT/DS309/8.

${ }_{95}$ Gao, "Taming the dragon..", supra, note 79 , at 376.
} 
negotiation. ${ }^{96}$ Thus, it is not difficult to understand that China felt a "loses of face" and worried the relationship with the US was threatened due to the US's sudden action.

Compared with the Steel case, China took a rather soft approach in the Value Added case. Several reasons contributed to this: first, China wanted to save face as soon as possible and to get rid of embarrassment; second, unlike the Steel case in which China had co-complainants, the Value case was China's first time of being a respondent and it lacked experience of resolving a dispute under the WTO. Although China had participated as a third party in WTO dispute settlement, it had only participated in no more than 20 cases before the Value Added case, and the cases that China had participated in as a third party were from varied backgrounds; third, as Gao mentioned in his article "legal actions could be interpreted by the Chinese leadership as something of great political and diplomatic significance. Thus, in order to avoid the political embarrassment, China would rather settle than have to endure the full vigour of the WTO dispute settlement system" ${ }^{97}$.

If we take the position that China took a hard approach in the Steel case which shows China's aggressive legalism and a soft approach in the Value Added case, then, which approach would be the trend for China under the WTO, Soft or Hard? The following China Auto Part case would be the case to illustrate the trend in the future.

\footnotetext{
96 Ibid., at 378.
}

97 Ibid. 


\section{The China Auto Part Case ${ }^{98}$}

China imposes a charge on imported auto parts but not domestic auto parts. China argues that the measures in the regulation are meant to keep law-breakers from exploiting the differences between tariff rates for importing entire automobiles and auto parts, and to protect consumer interests. The EU, US and Canada argued that the measures that China took were inconsistent with the GATT, the SCM Agreement ${ }^{99}$, the TRIMS $^{100}$ and China's obligation under its Accession Protocol. The WTO panel ruling was circulated in July 2008 and upheld US, EU and Canadian complaints that Chinese tax measures on imported auto parts result in unfair competition. In September 2008, China appealed against the Panel decision, according to Gao, "China has become somewhat impatient with consultations and indicated that it would not hesitate to take cases to the WTO if bilateral consultations do not work out." ${ }^{\text {101 }}$ On the $15^{\text {th }}$ of December 2008, the Appellate Body upheld the Panel findings. ${ }^{102}$

This case might be a signal that China is taking a more and more aggressive attitude towards WTO dispute settlement. The Chinese made a comment after the Appellate Body decision that "China welcomed the appeal body's ruling on the kit but regrets its other findings." 103 This is very different from China's earlier dispute

\footnotetext{
${ }^{98}$ Request for Consultations in China - Measures Affecting Imports of Automobile Parts received on April 13, 2006, WT/DS342/1, Panel Report in China-Measures Affecting Imports of Automobile Parts adopted on July 18, 2008,WT/DS342/R, and Appellate Body Report in China-Measures Affecting Imports of Automobile Parts on December 15,2008.

${ }^{99}$ Here refers to the Agreement on Subsidies and Countervailing Measures.

${ }^{100}$ Here refers to Trade-Related Investment Measures.

${ }^{101} \mathrm{Gao}$, "Taming the Dragon..", supra, note 79 at389.

${ }^{102}$ International Centre for Trade and Sustainable Development, "The WTO Appellate Body Rejects China's Auto Parts Appeal" 17 December 2008 http://ictsd.net/i/news/bridgesweekly/36490/, last accessed on 26 January 2008.

${ }^{103}$ Rediff India Abroad. "China loses auto case at WTO" December 16, 2008 http://www.rediff.com/money/2008/dec/16wto-china-loses-auto-case-at-wto.htm. The Kit here means Completely knocked down (CKD) and semi-knocked down (SKD) kits. The AB upheld China's claim that
} 
settlement strategies of either taking retaliatory actions or trying to have private negotiation with the complaints. More importantly, this case is China's first defeat in its WTO history and also the first case that China went through all the DSM procedures from consultation to appeal to the Appellate Body. This case brings China very valuable first-hand experience of the DSM procedure. In addition, rather than taking the view that a dispute might be seen as a sign of the break-up of a diplomatic relationship, this case shows China eventually realized trade issues are trade issues, and China seems to be getting used to fit itself in the rules based dispute settlement system under the WTO.

IV.3 Will China's Aggressive Legalism under the WTO Lead to A Flood of Disputes?

Although it shows a trend that China is becoming more and more legalistic under the WTO, there is no flood of disputes either brought by China or against China.

On one side, there are only three cases initiated by China from its accession in 2001 to present. According to Gao's "China so far has not shown any interest in opening up the flood-gate." ${ }^{104}$ Although this statement was made when USChina was the only complaint, there have only been two complaints since that time.

On the other side, there are eleven cases against China since accession. "After a six-year grace period, China's trading partners have started to make use of the dispute settlement mechanism against what they consider to be WTO-inconsistent trade practices." 105 The US has also indicated that "in 2008, the United States will continue to pursue vigorous bilateral engagement to resolve the serious disagreements that remain

the panel was wrong in ruling that Beijing's measure was inconsistent with paragraph 93 of its Accession Working Party Report, which allowed China to apply a tariff of not more than 10 per cent on SKDs and CKDs

${ }^{104}$ Gao, “Taming the Dragon..", supra, note 79 at 373.

${ }^{105}$ Marcia Don Harpaz, "Sense and Sensibilities of China and WTO Dispute Settlement", available at http://gradcon.huji.ac.il/2008/harp.doc, last accessed September 27, 2008. 
over a number of China's industrial policy measures", and "will continue to engage China and will closely monitor developments in an effort to ensure that China fully adheres to its services commitments." In addition, "If dialogue fails to address US concerns, however, the United States will not hesitate to take further actions .... including WTO dispute settlement, where appropriate." ${ }^{106}$ Although this statement could be interpreted as an indication of increasing disputes against China, the number of cases so far is not disproportionate to those brought against other major trading Members. ${ }^{107}$

To date, China has taken a conservative approach to dispute settlement. When conflicts arise between China and its trading partners, China appears to still prefer to solve the problems through consultation and negotiation. "From a review of China's early experience with the WTO DSU, we can say that China is behaving well in dispute settlement and is generally playing the role of a good WTO citizen." 108 China has also been constructive and conservative on the other side of dispute settlement. It has brought relatively few cases against other WTO Members. "At least to this point in time, China appears to be a constructive user of the WTO dispute settlement system. $\$ 109$

One reason that may contribute to there not being a flood of disputes towards China might be the WTO itself. According to Kong, The WTO dispute settlement has limited capacity, given tremendous responsibilities; the WTO has a tiny

\footnotetext{
${ }^{106}$ United States Trade Representative. "2007 Report to Congress On China's WTO Compliance", available at http://www.ustr.gov/assets/Document_Library/Reports_Publications/2007/asset_upload_file625_13692.pdf, last accessed September 28, 2008.

${ }_{107}$ World Trade Organization, "Trade Profiles--China", available at http://stat.wto.org/CountryProfile/WSDBCountryPFView.aspx?Language $=\mathrm{E} \&$ Country $=\mathrm{CN}$, accessed October 8, 2008.China's rank in world trade in 2006 (exports and imports) was number 3, after the US and the EC.

${ }^{108}$ Andrew L. Stoler, "China's Role in the World Trade Organization and the Doha Round of Multilateral Trade Negotiations", Second World Forum on China Studies, Shanghai, China, 21-22 September 2006., available at http://www.iit.adelaide.edu.au/speech/paper_final_210906_shanghai_sass_v2_1408.pdf. Internet p5, last accessed October 1, 2008.

${ }^{109}$ Ibid., at 9.
} 
team of professional staff in its secretariat and a tight budget. ${ }^{110}$ Not to mention more burdens will be put if the losing party appeals. According to Gao, "When the WTO DSM is used too frequently, it would not be long before the WTO DSM became jammed. In addition, as the WTO does not provide interim or retrospective relief, the trade partners have to suffer nullification or impairment to their trade interests during the process of the litigation." ${ }^{111}$ Hence, recognizing this, China does not want to get involved in the time consuming process while other members do not want to challenge China.

\footnotetext{
${ }^{110}$ Kong, "China and the WTO...", supra, note 66 at 153.

111 Gao, "Taming the Dragon..", supra, note 79 at 389.
} 


\section{Conclusion:}

Any type of international law, either hard or soft, has its own merits and advantages. Choice between them reflects members' wishes to model their relationship. This paper has analyzed the doctrines of soft law and hard law; examined their respective advantages and disadvantages; discussed the evolution from the GATT to the WTO to demonstrate that hard legalization regime is the more preferred approach in a multilateral framework; and the evolution from a soft law to a hard law approach which is also evidenced in China. Both the evolution of the GATT and China show that hard law is more appropriate in regulating trade affairs both at the international and the domestic levels.

Soft law's main advantages are its non-binding nature and flexibility which enable members to fashion their own way and set preferable schedules to solve their problems. However, the non-binding nature cannot ensure member's implementation of obligations and the flexibility leads to inconsistency of settling disputes. With hard legalization regime, explicit and precise rules enable members to know what is allowed and what is prohibited; binding obligations demonstrate members' willingness to make commitments; when conflicts arise, a neutral third party could give a binding decision to solve problems and even supervise the implementation of its decision.

Practice shows that hard legalization is more preferable in governing multilateral frameworks in which members from various backgrounds and their economic powers are not equal. This is evidenced in the evolution from the GATT to the WTO. The GATT provides a range of rules for its contracting parties to conduct economic transactions. However, the GATT was not meant to be a legal institution and it took a 
diplomatic approach to solve disputes among contracting parties. Over the years, as more and more members from various backgrounds acceded to the GATT, the diplomatic approach of the GATT could not satisfy members' needs for certainty and predictability. Contracting parties preferred a hard legal framework that has explicit rules, binding obligations and effective dispute settlement. By realizing this, the GATT contracting parties increasingly legalized and codified the GATT dispute settlement mechanism to enhance GATT's certainty and predictability. At the Uruguay Round, parties of the GATT agreed to establish the WTO to satisfy members' needs for a hard economic legal regime. The central success of the WTO is its dispute settlement mechanism by which members' rights can be enforced to the largest extent.

As a hard legal framework, the WTO is a rule orientated institution which provides more stability, fairness and predictability in international trade relationships than does a soft legal regime. According to Abbott, "The WTO incorporates several agreements with high levels of precision, obligation, and delegation to reduce intergovernmental transaction costs, reduces risk premiums for investors, constrains strategic governmental behaviours, provides guidance to bureaucrats, and promotes a variety of transparency functions." 112 The most successful pillar of the WTO is its dispute settlement mechanism which not only contains effective measures but also renders binding decisions; and implementation of the decisions will be supervised by the DSB.

China has also adopted a legalistic approach towards trade regulation. The Chinese traditional culture takes a soft approach to encourage people to solve conflicts without confrontation. However, after China's opening up, in order to encourage

${ }^{112}$ Abbott,"NAFTA legalization..." supra., note20 at 520. 
international transactions and to further its economic development, the Chinese domestic legal system has been taking a juridical approach. Guided by this approach, a number of laws have been modified to achieve certainty and predictability, judiciary competency has been improved to facilitate international businesses and this legal mobilization process is still on--going. After thirty years legal development since 1979, rules are more explicit, government intervention and reliance on Guanxi have been reduced, hence, people have confidence in the legal system and they feel more comfortable with litigation. The Chinese Open-Door policy and legal development form a good base for China to participate in the international organization regulating international trade since they signal the rule of law has been obtained in China.

As the Chinese legal system has been becoming more and more sophisticated and compatible with international law, China has been taking a more and more legalistic approach especially after China acceded to the WTO. Within China, the changing legal framework has begun to play an increasingly important role in governing economic activities, resolving civil disputes, enforcing law and order. People are confident in the legal system and litigation is becoming the principal means of dispute resolution compared with other alternative dispute methods. All of these show China is taking a more and more legalistic approach at domestic level.

China is also taking a more and more legalistic approach at the international level, especially in the WTO. In perceiving economic opportunities that the WTO brings, China initiated its accession to the WTO in 1987 and eventually acceded to the WTO in late 2001. As the largest trade framework, the WTO not only provides economic opportunities but also the WTO's hard law characteristics protects China's 
rights and reduces intergovernmental transaction costs, reduce risks for private sectors, promote transparency and restrain strategic political behaviours. Upon accession to the WTO, China is able to participate in the WTO dispute settlement mechanism that is central to the success of the WTO and the multilateral trading system. On the other side, the accession also shows China's willingness to make commitments through binding obligations.

Due to its Confucian culture which encourages dispute avoidance, lack of knowledge of the WTO rules and fear that disputes before the Panel would be perceived as signals of break up with trading partners; China was reluctant to use the WTO dispute settlement system. Over the years, by having a better understanding that the goal of dispute settlement is to solve economic conflicts rather than to signal break up among parties, China has gradually become more comfortable with the DSM and has taken a more legalistic approach to protect its rights under the WTO. This increasing legalistic approach should not be viewed negatively but should be considered as China's adjustment to the norms of the international economic order.

China's approach from a reluctant user to an aggressive user of the dispute settlement mechanism is consistent with the changing nature from GATT to the WTO. China, as a major trading force, could utilize the WTO rules either offensively or defensively. China has been regarded as a conservative user that prefers to solve conflicts through informal negotiation before going to adjudication, but one that will use adjudication if necessary.

After analyzing hard law and soft law and their applications both at the international and domestic levels; the evolution of the juridical approach from the GATT 
to the WTO; and the change from a diplomatic to a legalistic approach in China, one will find that hard law and legalistic approach are more appropriate for regulating economic transactions.

This is not to say soft law is useless or that soft law does not play any role. Instead, the role that soft law plays at the international level should never be underestimated. As we look into the WTO framework, soft aspects such as negotiation and conciliation are also concluded to make the whole framework achieve flexibility to some extent. Besides the WTO, there are also successful soft economic legal frameworks, such as APEC. APEC is "the only inter-governmental grouping in the world operating on the basis of non-binding commitment, open dialogue and equal respect for the views of all participants." 113 Despite its soft nature, APEC has also made significant gains in facilitating economic development in this region. Since APEC's inception in 1989, APEC's total trade has grown $395 \%$ as of $2008^{114}$. The APEC's soft characteristics represent cultural preference of its 21 members, two thirds of whom are from Asia region, which are all influenced by Confucianism from China. Although there have been calls for legalizing the APEC from the Western members such as the US, dominate Asian preference for informal institution rejected those calls and the APEC remains as a soft legal framework.

In the end, while hard law is more appropriate in regulating economic transactions, the importance of the soft law should never be underestimated. While a hard legalization reflects members' willingness to make commitment, soft legalization can also achieve development through self-constrains.

\footnotetext{
113 "about APEC", Supra, note11

114 Ibid.
} 


\section{Appendix 1}

\section{Supreme People's Court Notice on People's Courts' Application of Law in Handling Commercial Cases Involving Foreign Elements}

Many People's Courts' awareness of the application of law is weak, even so weak as to have carried on any analysis on the application of law in the judgments. Different from domestic cases, there are many particularities and complexities in cases involving foreign elements, and the application of law is one of the most important aspects among them. In order to try commercial cases involving foreign elements well, the People's Courts must strengthen their awareness of the application of law. The correct application of law is the basis of just judgment. The People's Courts must not take applying domestic laws for granted regardless of foreign law, and therefore draw a conclusion on the application of law without reasoning. Instead, the People's Courts should make an analysis and determination on the applicable law of the case in question in the judgment document and give its applicable law of the case in question in the judgment document and give its reason in detail. As to the above-mentioned problems, the People's Courts at all levels should pay great attention to them in trial practice in the future and summarize the experience and lessors constantly so as to heighten the level of judgment documents of commercial cases involving foreign elements further and safeguard the image of the just administration of justice of the People's Courts of our country. 


\section{Appendix 2}

Growth of Litigation, 1978-97 (accepted cases in courts of first instance) ${ }^{115}$

\begin{tabular}{|l|l|l|l|}
\hline Year & Economic & Civil & Administrative \\
\hline 1978 & & 285,000 & \\
\hline $1979.6-82.12$ & 49,000 & & \\
\hline 1981 & & 658,000 & \\
\hline 1982 & & 770,000 & \\
\hline 1983 & 44,000 & 747,000 & \\
\hline 1984 & 85,700 & & \\
\hline 1985 & 226,600 & 846,000 & \\
\hline 1986 & 308,393 & 989,409 & 632 \\
\hline 1987 & 367,156 & $1,213,219$ & 5,240 \\
\hline 1988 & 513,615 & $1,455,130$ & 9,273 \\
\hline 1989 & 690,765 & $1,815,385$ & 9,934 \\
\hline 1990 & 598,314 & $1,851,897$ & 13,006 \\
\hline 1991 & 563,260 & $1,880,635$ & 25,667 \\
\hline 1992 & 650,601 & $1,948,786$ & 27,125 \\
\hline 1993 & 894,410 & $2,089,257$ & 27,911 \\
\hline 1994 & $1,053,701$ & $2,383,764$ & 35,083 \\
\hline 1995 & $1,278,806$ & $2,718,533$ & 52,596 \\
\hline 1996 & $1,519,793$ & $3,093,995$ & 79,966 \\
\hline 1997 & $1,483,356$ & $3,277,572$ & 90,557 \\
\hline
\end{tabular}

${ }^{115}$ Pei, Supra.. note62, p185 


\section{Appendix 3}

Dispute cases involving China: (compiled from WTO website http://www.wto.org/english/tratop_e/dispu_e/dispu by country_e.htm)

\begin{tabular}{|c|c|c|c|}
\hline Short Name & Complainant & Respondent & $\begin{array}{l}\text { Request for } \\
\text { Consultations }\end{array}$ \\
\hline US - Steel Safeguards & China & United States & 26 March 2002 \\
\hline $\begin{array}{l}\text { Coated free sheet } \\
\text { paper }\end{array}$ & China & United States & 14 September 2007 \\
\hline $\begin{array}{l}\mathrm{A} / \mathrm{D} \text { and } \mathrm{C} / \text { Duties on } \\
\text { Certain Products }\end{array}$ & China & United States & 19 September 2008 \\
\hline $\begin{array}{l}\text { VAT on integrated } \\
\text { circuits }\end{array}$ & United States & China & 18 March 2004 \\
\hline China - Auto Parts (a) & European Communities & China & 30 March 2006 \\
\hline China - Auto Parts (b) & United States & China & 30 March 2006 \\
\hline China - Auto Parts (c) & Canada & China & 13 April 2006 \\
\hline China - Taxes (a) & United States & China & 2 February 2007 \\
\hline China - Taxes (b) & Mexico & China & 26 February 2007 \\
\hline $\begin{array}{l}\text { China - Intellectual } \\
\text { Property Rights }\end{array}$ & United States & China & 10 April 2007 \\
\hline $\begin{array}{l}\text { China - Audiovisual } \\
\text { Services }\end{array}$ & United States & China & 10 April 2007 \\
\hline $\begin{array}{l}\text { financial information } \\
\text { services (a) }\end{array}$ & European Communities & China & 3 March 2008 \\
\hline $\begin{array}{l}\text { financial information } \\
\text { services (b) }\end{array}$ & United States & China & 3 March 2008 \\
\hline $\begin{array}{l}\text { financial information } \\
\text { services (c) }\end{array}$ & Canada & China & 20 June 2008 \\
\hline
\end{tabular}




\section{Bibliography}

\section{Books}

Caputo Tullio, Charles Reasons, Augistine Brannigan \& Mark Kennedy. Law and Society, a Critical Perspective, Toronto: Harcourt Brace Jovanovich, Canada 1989

D’Amato Anthony. International Law: Process and Prospect, New York: Transnational Publishers Inc. 1995

D'Amato Anthony. "Chapter 5 - Soft Law", in D'Amato, Anthony D'Amato and Kirsten Engel, International Environmental Law Anthology, Philadelphia US: Anderson Publishing Company 1997

Hudec, Robert. "The role of the GATT Secretariat in the Evolution of the WTO Dispute Settlement Procedure" in Jagdish Bhagwati and Matthias Hirsch, eds., The Uruguay Round and Beyond, Ann Arbor: University of Michigan Press 1998

Hudec Robert E., Enforcing International Trade Law. The evolution of the Modern GATT Legal System. Salem: Butterworth Legal Publishers 1993

Jackson H. John. The Jurisprudence of GATT \& The WTO, New York: Cambridge University Press, 2000

Kirton, John \& Trebilcock Michael J. Hard Choices, Soft Law: Voluntary Standards in Global Trade, Environment, and Social Governance, Vermont USA: Ashgate Publishing, 2004

Kong, Qingjiang. China and The World Trade Organization, A Legal Perspective, New Jersey: World Scientific Publishing Co. 2002

Pei, Minxin. "Does Legal Reform Protect Economic Transactions? Commercial Disputes in China" in Peter Murrell Assessing the Value of Law in Transition Economies, Ann Arbor: University of Michigan Press, 2001

Petersmann, Ernst-Ulrich. The GATT-WTO Dispute Settlement System International Law, International Organizations and Dispute Settlement, Boston : Kluwer Law International 1997 


\section{Journal Articles}

Abbott, Frederick M. "NAFTA and the Legalization of World Politics: A Case Study", International Organization 54 (2000): 519-547

Abbott, Kenneth W. \& Duncan Snidal. "Soft and Hard Law in International Governance", International Organization 54 no3 (2000): 421-456

Abbott, Kenneth W., Ribert O, Keohane, Andrew Moravcsik, Anne-Marie Slaughter, hand Duncan Snidal "The Concept of Legalization", International Organization 54 no.3 (2000): $401-419$

Bowman, D Herbert. "The Adversarial System-Origin and Practice in the United States with a comment on Recent Changes in Chinese Criminal Procedure", US-China Law Review. Vol 1 no1 (2004)

Chad Brown P. "China's WTO Entry: Antidumping, Safeguards, and Dispute Settlement” Brandeis University August 2007. available at http://www.nber.org/books in progress/china07/bown8-13-07.pdf, last accessed on Oct $30,2008$.

Chinkin, C.M.. "The Challenge of Soft Law, Development and Change in International Law", International \& Comparative Law Quarterly 38 (1989): 850-866

Davey, William J. "The WTO Dispute Settlement System: How Have Developing Countries Fared?" Draft, March 8, 2007, p31 available at

http://www.luc.edu/law/activities/publications/ilrsymposium/2008sym/davey wto disput e paper.pdf, last accessed September 25, 2008.

Davidson, Paul. To Bind or not to Bind, this is a question International Law and the Role of APEC in the Governance of a Free Trade Area of the Asia Pacific (FTAAP) a revised version of a paper presented at The Second All China Economics (ACE) International Conference, APEC Study Centre, City University of Hong Kong, Hong Kong, on December $12-14,2007$, unpublished. Copy on file with the author

Dong Fengxia \& Helen H.Jensen. "The Challenge of Conforming to Sanitary and Phytosanitary Measures For China's Agricultural Exports", MATRIC Working Paper 04MWP8, available at Http://www.card.iastate.edu/publications/DBS/PDFFiles/04mwp8.pdf, last_accessed on September 20, 2008

Gao Henry, "Aggressive Legalism: The East Asian Experience and Lessons for China", available at http://www.worldtradelaw.net/articles/gaolegalism.pdf, last accessed October $14,2008$. 
Gao, Henry. "Taming the Dragon: China's Experience in the WTO Dispute Settlement System", Legal Issues of Economic Integration, 34 no4 (2007): 369-392

Gold, Joseph. "Strengthening the Soft International Law of Exchange Agreements", The American Journal of International Law 77 no 3 (1983): $443-489$

Harpaz, Marcia Don, "Sense and Sensibilities of China and WTO Dispute Settlement", available at http://gradcon.huji.ac.11/2008/harp.doc last accessed on September 27, 2008

Hoekman Bernard, Aaditya Mattoo \& Philip English, "Development, Trade, and the WTO: A Hand Book" Washington: World Bank 2002, available at http://wwwwds.worldbank.org/servlet/WDSContentServer/WDSP/IB/2004/08/19/000160016 20040 819140633/Rendered/PDF/297990018213149971x.pdf, last_accessed November 13, 2008.

Klabbers, Jan. "Institutional Ambivalence by Design: Soft Organizations in International Law", Nordic Journal of International Law 70 no3 (2001): 403-421

Panel Report in United States-Restrictions on Imports of Cotton and Man-Made Fibre Underwear adopted on 8 November 1996, WT/DS24/R/Corr.1 and Appellate Body Report United States - Restrictions on Imports of Cotton and Man-Made Fibre Underwear adopted on 10 February 1997, WT/DS24/AB/R., available at http://www.wto.org/english/tratop e/dispu e/cases e/ds24 e.htm, last accessed November 14, 2008.

Pekkanen Saadia M., "Aggressive Legalism: The Rules of the WTO and Japan's Emerging TradeStrategy", The World Economy 24 no 5(2001): 707-737

Posner A. Eric. "The Decline of the International Court of Justice" University of Chicago Law and Economics, working paper No 233, States represented on the first court (ICJ)

Scogin, Hugh T. "Between Heaven and Man: Contract and the State in Han Dynasty China", Southern California Law Review Vol63 no 5 (1990): 1326-1405

Stoler, Andrew L., "China's Role in the World Trade Organization and the Doha Round of Multilateral Trade Negotiations", Second World Forum on China Studies, Shanghai, China, 21-22 September 2006, available at http://www.iit.adelaide.edu.au/speech/paper_final_210906_shanghai_sass_v2_1408.pdf, last accessed October 1, 2008,

Tsang, Eric W.K. "Can Guanxi Be a Source of Sustained Competitive Advantage for Doing Business", Academy of Management Executive 12 no 2 (1998): 64-73

United State Trade Representative. "2006 Report to Congress on China's WTO Compliance", available at 
http://www.ustr.gov/assets/Document_Library/Reports_Publications/2006/asset upload f ile688 10223.pdf, last accessed on September 19, 2008

United States Trade Representative. "2007 Report to Congress On China's WTO Compliance", available at http://www.ustr.gov/assets/Document_Library/Reports_Publications/2007/asset_upload f ile625_13692.pdf, last accessed September 28, 2008

Yeung Irene Y.M. \& Rosalie L. Tung. "Achieving Business Success In Confucian Societies: The Importance of Guanxi (connections)", Organization Dynamics 25 no2 (1996): 54-65

Zhang Yuqing \& Danhan Huang, "The New Contract Law in the People's Republic of China and the UNIDROIT Principles of International Commercial Contract: A Brief Comparison", available at $\mathrm{http}: / / \mathrm{www}$.unidroit.org/english/publications/review/articles/2000-3.htm, last accessed Oct 10, 2008.

\section{Electronic Sources from Official Institution Website}

APEC Official website. About APEC available at http://www.apec.org/apec/about_apec.html, last assessed on 20 June, 2008

China Daily. "Wu: US Piracy Case Will Harm Trade Ties". 24 April 2007 available at http://www.chinadaily.com.cn/china/2007-04/24/content_858638.htm Internet $\mathrm{http} / / /$ Plato.Stanford.edu/entries/legal-positivism/ Internet http://www.wto.org/english/tratop e/dispu_e/dispu by country e.htm, last accessed Oct 252008.

International Court of Justice. "The Court" available at http://www.icjcij.org/court/index.php?p1=1, last accessed Nov 8, 2008,

Ministry of Commerce, the People's Republic of China "Minister: China prefers to solve trade friction through consultations", Monday, March 12, 2007 Posted: 01:27 BJT(1727 GMT) XinHua, available at http://english.mofcom.gov.cn/aarticle/subject/hsessions/lanmua/200703/2007030445063 $\underline{0 . \mathrm{html}}$, last accessed September 24, 2008.

People's Daily Online. "China Appeals WTO Ruling on Auto Parts Import Measures", 16 September 2008, available at http://english.peopledaily.com.cn/90001/90778/90858/90863/6499703.html , last accessed 26 September, 2008, 
Stanford Encyclopedia Of Philosophy. "Legal Positivism", available at http://plato.stanford.edu/entries/legal-positivism/ last accessed June 152008.

The Chinese Embassy. "Transcript of Press Conference by Mr. Bo Xilai, Minister of Commerce of the People's Republic of China", May 30, 2005, available at http://gr.chineseembassy.org/eng/xwdt/t200344.htm, last accessed September 24, 2008.

The WTO official website. "Disputes by Countries", available at http://www.wto.org/english/tratop e/dispu_e/dispu by country e.htm, last accessed October 20,2008 ,

World Trade Organization, "Trade Profiles--China", available at http://stat.wto.org/CountryProfile/WSDBCountryPFView.aspx?Language=E\&Country= $\underline{\mathrm{CN}}$, last accessed October 8, 2008

\section{International Agreements}

Agreement on Subsidies and Countervailing Measures (SCM), available at http://www.wto.org/english/docs e/legal e/24-scm 01 e.htm, last accessed on December 8,2008

Agreement on Trade-Related Investment Measures (TRIM), available at http://www.wto.org/english/docs e/legal e/18-trims.pdf, last accessed on Dec 8, 2008

Charter of the United Nations, available at http://www.un.org/aboutun/charter/ http:// www.wto.org/english/docs e/legal.htm, last accessed on December 8, 2008.

Marrakesh Agreement Establishing the World Trade Organization, available at http://www.wto.org/english/docs_e/legal_e/04-wto e.htm, last accessed on December 8, 2008.

Understanding on Rules and Procedures Governing the Settlement of Disputes (DSU), available at http://www.wto.org/english/docs_e/legal_e/28-dsu_e.htm accessed on December 82008

\section{WTO Panel Reports (available on the WTO website)}

Panel Report in Japan-Import Quotas on Dried Laver and Seasoned Laver adopted February 1,2006, WT/DS323/R and Mutually Agreed Solution in Japan-Import Quotas on Dried Laver and Seasoned Laver adopted on January 27 2006, WT/DS323/5, available at http://www.wto.org/english/tratop_e/dispu_e/cases_e/ds323_e.htm, last accessed December 102008

\section{WTO Appellate Body Reports (available on the WTO website)}

Panel Report in United States-Definitive Safeguard Measures on Imports of Certain Steel Products adopted on July 11 2003, WT/DS259/R and Appellate Body Report in 
United States-Definitive Safeguard Measures on Imports of Certain Steel Products adopted on November 10 2003, WT/DS259/AB/R, available at

http://www.wto.org/english/tratop e/dispu e/cases e/ds259 e.htm, last accessed

December 102008

Panel Report in China-Measures Affecting Imports of Automobile Parts adopted on July 18, 2008,WT/DS342/R, and Appellate Body Report in -Measures Affecting Imports of Automobile Parts adopted on December 15, 2008, WT/DS342/AB/R, available at http://www.wto.org/english/tratop e/dispu e/cases e/DS342 e.htm, last accessed January 15, 2009.

\section{Disputes at Consultation Stage (available on the WTO website)}

Request for Consultation received in United States-Preliminary Anti-Dumping and Countervailing Duty Determinations on Coated Free Sheet Paper from China on 14 September, 2007.WT/DS368/1, available at http://www.wto.org/english/tratop e/dispu e/cases_e/DS368 e.htm, last accessed December 102008

Request for Consultations in United States-Definitive Anti-Dumping and Countervailing Duties on Certain Products from China, received on 19 September, 2008. WT/DS379/1, available at http://www.wto.org/english/tratop e/dispu_e/cases_e/DS379 e.htm, last accessed December 102008.

\section{Mutually Agreed Solution (available on the WTO website)}

Request for Consultation in China-Value-Added Tax on Integrated Circuits was received on March 18,2004,WT/DS309/1 and Mutually Agreed Solution adopted on October 6, 2005.WT/DS309/8, available at http://www.wto.org/english/tratop_e/dispu e/cases_e/DS309_e.htm, last accessed December 102008

\section{International Case}

G. v. Ford Motor CO. (1981) 119 CA 3d 757 